\title{
Impact of Water Recovery from Wastes on the Lunar Surface Mission Water Balance
}

\begin{abstract}
:
Future extended lunar surface missions will require extensive recovery of resources to reduce mission costs and enable self-sufficiency. Water is of particular importance due to its potential use for human consumption and hygiene, general cleaning, clothes washing, radiation shielding, cooling for extravehicular activity suits, and oxygen and hydrogen production. Various water sources are inherently present or are generated in lunar surface missions, and subject to recovery. They include: initial water stores, water contained in food, human and other solid wastes, wastewaters and associated brines, ISRU water, and scavenging from residual propellant in landers.
\end{abstract}

This paper presents the results of an analysis of the contribution of water recovery from life support wastes on the overall water balance for lunar surface missions. Water in human wastes, metabolic activity and survival needs are well characterized and dependable figures are available. A detailed life support waste model was developed that summarizes the composition of life support wastes and their water content. Waste processing technologies were reviewed for their potential to recover that water. The recoverable water in waste is a significant contribution to the overall water balance. The value of this contribution is discussed in the context of the other major sources and loses of water. Combined with other analyses these results provide guidance for research and technology development and down-selection. 


\title{
Impact of Water Recovery from Wastes on the Lunar Surface Mission Water Balance
}

\author{
John W. Fisher ${ }^{1}$ and John A. Hogan ${ }^{2}$ \\ NASA Ames Research Center, Moffett Field, CA, 94035-1000 \\ Gregory S. Pace ${ }^{3}$ \\ Satellite Systems and Technical Services, Lockheed Martin IS\&GS Defense, Moffett Field, CA, 94035-1000 \\ and \\ Kanapathipillai Wignarajah ${ }^{4}$ \\ Dynamac Inc., Moffett Field, CA, 94035-1000
}

\begin{abstract}
Future extended lunar surface missions will require extensive recovery of resources to reduce mission costs and enable self-sufficiency. Water is of particular importance due to its potential use for human consumption and hygiene, general cleaning, clothes washing, radiation shielding, cooling for extravehicular activity suits, and oxygen and hydrogen production. Various water sources are inherently present or are generated in lunar surface missions, and subject to recovery. They include: initial water stores, water contained in food, human and other solid wastes, wastewaters and associated brines, ISRU water, and scavenging from residual propellant in landers. This paper presents the results of an analysis of the contribution of water recovery from life support wastes on the overall water balance for lunar surface missions. Water in human wastes, metabolic activity and survival needs are well characterized and dependable data are available. A detailed life support waste model was developed that summarizes the composition of life support wastes and their water content. Waste processing technologies were reviewed for their potential to recover that water. The recoverable water in waste is a significant contribution to the overall water balance. The value of this contribution is discussed in the context of the other major sources and losses of water. Combined with other analyses these results provide guidance for research and technology development and down-selection.
\end{abstract}

\footnotetext{
${ }^{1}$ Lead Engineer - Life Support, Bioengineering Branch, NASA Ames Research Center, MS 239-15, Moffett Field, CA, 94035-1000.

${ }^{2}$ Environmental Scientist, Bioengineering Branch, NASA Ames Research Center, MS 239-15, Moffett Field, CA, 94035-1000.

${ }^{3}$ Mechanical Engineer, Bioengineering Branch, NASA Ames Research Center, MS 239-15, Moffett Field, CA, 94035-1000.

${ }^{4}$ Senior Scientist, Bioengineering Branch, NASA Ames Research Center, MS 239-8, Moffett Field, CA, 940351000 .
} 


\section{Nomenclature}

$\begin{array}{ll}\text { ARC } & =\text { Ames Research Center } \\ \text { BVAD } & =\text { Baseline Values and Assumptions Document } \\ \mathrm{CM} & =\text { Crew Member } \\ \mathrm{CSSE} & =\text { Constellation Space Suit Element } \\ \mathrm{ECLSS} & =\text { Environmental Control and Life Support Systems } \\ \mathrm{ELS} & =\text { Exploration Life Support } \\ \mathrm{ESM} & =\text { Equivalent System Mass } \\ \mathrm{EVA} & =\text { Extra Vehicular Activity } \\ \text { ISRU } & =\text { In Situ Resource Utilization } \\ \text { LCVG } & =\text { Liquid Cooling and Ventilation Garment } \\ \text { LER } & =\text { Lunar Electric Rover } \\ \text { LSS } & \text { Lunar Surface System } \\ \text { MAG } & =\text { Maximum Absorbency Garment } \\ \text { OPIS } & =\text { Online Project Information System } \\ \text { PLSS } & =\text { Portable Life Support System } \\ \text { RCA } & \text { Rapid Cycling Amine } \\ \text { SIMA } & =\text { Systems Integration Modeling and Analysis } \\ \text { SMMB } & =\text { Surface Mission Mass Balance } \\ \text { SWME } & =\text { Space Suit Water Membrane Evaporator } \\ \text { WMS }=\text { Waste Management System } & \end{array}$

\section{Introduction}

$\mathrm{T}$ HE development of safe and cost-effective life support systems for long-duration lunar surface missions requires a thorough analysis to effectively select and integrate the numerous life support sub-systems. One of the critical issues associated with a lunar surface mission is the very high cost of delivering payload to the surface. This cost acts as a major driver to reduce the amount of initial payload and subsequent resupply required, which subsequently drives the need for closing material loops. One of the primary ways to reduce mission mass is to recover water, as large quantities are consumed and released by the crew on a daily basis. The degree of water recovery needed within the system will be mostly driven by the cost of recovery vs. the cost of supply. Additionally, a need for mission self-sufficiency can also become a driver, which suggests a high degree of water recovery, even if the cost of recovery exceeds supply costs.

Determining the optimal amount and means of water recovery requires a system-level analysis that identifies all significant water inputs and outputs, as well as the potential means to collect, process and reuse this water. Creating a system-level water mass balance allows various technology options and operational assumptions to be investigated, and facilitates technology development and down-selection. A number of different sub-systems participate in the overall water mass balance, including potable water supply, water contained in food, human metabolism, using fuel cells to scavenge water from residual $\mathrm{H}_{2}$ and $\mathrm{O}_{2}$ from lunar landers, water loss from extra vehicular activity (EVA) suits, processing of humidity condensate, urine and hygiene wastewater, water in feces and trash, and in situ resource utilization (ISRU) water production.

A major focus of this study was to evaluate the waste management system's (WMS) potential effects on the overall system water balance. Solid wastes can contain substantial amounts of free water that are readily recovered using waste drying techniques. In addition, water produced through mineralization (e.g., thermal oxidation or pyrolysis) of wastes is another potential water source. The amount of water that can be recovered from wastes will be a function of the types and amounts of wastes, the total free water contained, the waste susceptibility to processing for water removal, and the type of processor employed. In addition to the benefits of recovering water 
from wastes, drying is also an effective means of stabilizing wastes, and can serve other waste management requirements.

This analysis effort consisted of two major elements. The first was the development of a lunar surface waste model that provides an estimate of the types, amounts, and water content of the anticipated wastes. The second element was a system level analysis of the potential effects of waste processing for water recovery to influence the system level water mass balance for a long-duration lunar surface mission. The system level analysis required detailed consideration of some of the controlling factors on the water balance including water scavenging, EVA, and food hydration. An analysis tool (spreadsheet format) was developed to conduct the overall water balance.

\section{Solid Waste Model Development for a Long Duration Lunar Surface Mission}

Prior to performing a system level trade study to evaluate the potential effect of recovering water from waste, it is necessary to have a waste model that reasonably characterizes the anticipated waste streams. Similarly, in combination with WMS requirements and drivers, this waste model will drive technology R\&TD and downselection. A significant amount of previous work has been performed that identified potential wastes from various historical mission scenarios, both from post-mission analyses of discarded wastes as well as supply uploading information. This information is largely kept current within the Exploration Life Support (ELS) project's Baseline Values and Assumptions Document. ${ }^{1}$ While waste summary information in that document is presented to allow researchers to approximate certain waste flows, there is no widely-established waste model for a long-duration lunar surface mission at this time. Therefore, mission analyses are often conducted using analysis-specific (customized) waste models that employ varying assumptions and design values.

A major goal of this waste model development effort is to generate a central "working document" that is widely accessible and that could serve as a focal point for continuing refinement. Developing this type of waste model for new classes of missions that are still in initial planning creates a significant amount of uncertainty. Therefore, it is anticipated that data contained in this model could change significantly as mission definition and development progresses. This waste model is therefore not intended to be a final product, but rather a beginning point. With this in mind, the model was constructed using a spreadsheet format that allows users to readily change mission assumptions, mission design values and even add analytical functionality.

A full characterization of wastes requires a large number of parameters to be identified. The most pertinent waste parameters that require examination for the water balance study include the waste type, mass and moisture content, and were the central data collected for this model development. Additional data will eventually be needed for a more refined analysis to support detailed waste processing equipment selection, sizing and integration studies. These additional data may include waste volume in relevant waste mixtures and under different levels of compaction (e.g., none, manual, mechanical, heat-melt), materials of construction, elemental composition, biodegradability, and others. As such, the wastes would need to be generated in a realistic fashion and processed in actual Waste Management System (WMS) technologies to obtain much of this information.

\section{A. Model Development and Characteristics}

The data collected for this model were obtained or derived from a number of sources including various Exploration Life Support (ELS) program documents, ${ }^{1,2,3}$ uploading data, assorted technical papers, textbooks and previous waste model studies. The general approach was to identify the anticipated wastes and to classify them according to waste similarity and/or subsystem/operation. Although certain waste streams are currently difficult to predict or unplanned (e.g., experiment wastes, biomass production), those classes were included to ensure they are addressed as data become available.

The model was designed to allow the user to select various mission parameters. This includes the crew size during the nominal mission, as well as during the mission overlap period. The mission overlap period is that time between when a new crew arrives and the old crew departs. Estimates appear to vary with exactly how long this overlap period will be, but 30 days appears to be the current maximum. Likewise, the mission duration and overlap period are specified as model parameters. Knowledge of the average percent of female crewmembers is required because males and females incur different hygiene waste loads.

EVA is accounted for by requesting the average number of EVA sorties per day. Currently, the only calculation that EVA pertains to is the generation of Maximum Absorbency Garments (MAGs) (i.e., diapers). It is assumed that each EVA performed by a crewmember requires a fresh MAG. An important feature of the MAG as a waste item is that it may contain human urine and feces. It is also unclear what percentage of urine and fecal wastes will be contained in a used MAG, but it is assumed that the crew will be resistant to soil the MAG during EVA. It was assumed that MAGs contain $10 \%$ of fecal waste and $33 \%$ of urine on the day of an EVA. 
Another related assumption is that a certain fraction of defecations will be diarrheal. This is important because diarrhea will contain much higher amounts of water than nominal feces. The programmatic assumption ${ }^{3}$ is that each diarrheal event would be about $0.5 \mathrm{~L}$. Additionally, it is assumed that the same amount of fecal solids is contained in that volume, and that the remainder is composed of water. It was assumed that one defecation per month was diarrheal.

The data inputs for the actual mass and water content of wastes expected for the model waste components were provided as nominal, minimum and maximum values. The nominal values were selected to be the most likely value at this point in the mission planning. The minimum and maximum values were provided to give a reasonable design range.

Using the various mission parameters, waste component design mass values and moisture content are calculated and listed separately in a separate area of the worksheet. These data are then summarized in the final section to allow the user to easily discern the totals of various waste stream component mixtures.

\section{B. Lunar Outpost Waste Model Results}

Because of the actual size of the model spreadsheet with accompanying notes, it cannot be reasonably presented "as-is" in the text of this paper; however, a summary of the model data is presented below. The file is present on the ELS Online Project Information System (OPIS) website.

Table 1 shows the mission parameters that were used to calculate the nominal waste model results. Again, it must be noted that certain design assumptions are currently under development, and significant changes in the assumptions are likely with time. Therefore, it is valuable to approach the results of this model as preliminary guidance, rather than final results.

Table 1. General mission assumptions for the lunar outpost waste model.

\begin{tabular}{|l|c|l|} 
Mission Parameters: & \multicolumn{3}{|c|}{$\begin{array}{l}\text { Nominal } \\
\text { Design } \\
\text { Values }\end{array}$} \\
\hline Crew Size (nominal crew) & 4 & CM \\
\hline $\begin{array}{l}\text { Crew Size (mission overlap } \\
\text { period) }\end{array}$ & 8 & CM \\
\hline $\begin{array}{l}\text { Mission Duration (nominal } \\
\text { crew) }\end{array}$ & 180 & days \\
\hline $\begin{array}{l}\text { Mission Duration (mission } \\
\text { overlap period) }\end{array}$ & 30 & days \\
\hline $\begin{array}{l}\text { Ave. \% Female } \\
\text { Crewmembers }\end{array}$ & 25 & $\%$ \\
\hline $\begin{array}{l}\text { Total Crew Days } \\
\text { Number of EVA Sorties/d }\end{array}$ & 2.86 & /day \\
\hline Number of EVA Sorties & 600 & $/$ mission \\
\hline$\%$ of Defecations as Diarrhea & 3.3 & $\%$ \\
\hline
\end{tabular}

The waste model uses the missions and waste composition to calculate useful summaries. Table 2 displays the results of the total mass of lunar outpost mission wastes (as-is) as well as the water mass contained in that waste mass for the mission parameters presented in Table 1. The associated moisture contents for the same waste mixtures are presented in Table 3. To facilitate comparison without reference to mission duration or crew size, the average daily crewmember production rates were also calculated and are presented in Table 4.

The principal finding from the data in Tables 1 - 4 is that there is a substantial amount of water in the anticipated wastes in a lunar outpost mission. With respect to the entire waste stream (without wastewater brine), each crewmember produces a nominal average of $1.49 \mathrm{~kg} / \mathrm{CM}$-day at a moisture content of $41.9 \%$, or $0.62 \mathrm{~kg}$ of water/CM-day. Over this mission duration (180 days with a $30 \mathrm{crew}$ overlap), $599 \mathrm{~kg}$ of unbound water is expected to be contained the solid waste. As waste processing systems can readily remove greater than $90 \%$ of the moisture in waste (see later), it is appears prudent to explore the potential for recovery of water.

The data in Tables 2-4 were presented in a manner that facilitates understanding how waste production rates will vary in accordance with future WMS design. For example, the nominal crewmember production rates will increase from 1.49 to $1.90 \mathrm{~kg} / \mathrm{CM}$-day if wastewater brines are not further dried for both water recovery and volume reduction. This significant increase, which is mostly water, points to serious consideration of drying wastewater brines. 
Table 2. Total mission waste (as-is) and water masses for various waste mixtures.

\begin{tabular}{|c|c|c|c|c|c|c|c|}
\hline $\begin{array}{l}\text { Lunar Outpost Waste Model } \\
\text { Summary -Total Mass }(\mathrm{kg})\end{array}$ & $\begin{array}{l}\text { Waste } \\
\text { Mass } \\
\text { (Nominal) }\end{array}$ & $\begin{array}{l}\text { Waste } \\
\text { Mass } \\
\text { (Minimum) }\end{array}$ & $\begin{array}{l}\text { Waste } \\
\text { Mass } \\
\text { (Maximum) }\end{array}$ & $\begin{array}{l}\text { Water } \\
\text { Mass } \\
\text { (Nominal) }\end{array}$ & $\begin{array}{l}\text { Water Mass } \\
\text { (Minimum) }\end{array}$ & $\begin{array}{l}\text { Water } \\
\text { Mass } \\
\text { (Maximum) }\end{array}$ & Notes: \\
\hline $\begin{array}{l}\text { Waste (no brine or brine } \\
\text { solids) }\end{array}$ & 1431 & 1213 & 1765 & 599 & 471 & 869 & $\begin{array}{l}\text { Represents total of all wastes (as-is) and contained } \\
\text { free water without brine products. }\end{array}$ \\
\hline $\begin{array}{l}\text { Waste (includes brine and } \\
\text { brine solids) }\end{array}$ & 1825 & 1815 & 2137 & 923 & 983 & 1166 & $\begin{array}{l}\text { Represents total of all wastes (as-is) including } \\
\text { wastewater brine. }\end{array}$ \\
\hline Waste (includes brine solids) & 1502 & 1304 & 1839 & 599 & 471 & 869 & $\begin{array}{l}\text { Represents total of all wastes (as-is) without } \\
\text { wastewater brine, but with brine solids (Assumes } \\
\text { brine drying to } 100 \% \text { ) }\end{array}$ \\
\hline $\begin{array}{l}\text { Waste (no brine/solids, } \\
\text { laundry items) }\end{array}$ & 1102 & 917 & 1403 & 571 & 446 & 815 & $\begin{array}{l}\text { Represents total of all wastes (as-is) without } \\
\text { wastewater brine/solids or laundry items }\end{array}$ \\
\hline $\begin{array}{l}\text { Waste (no brine/solids, } \\
\text { laundry, feces) }\end{array}$ & 971 & 814 & 1263 & 472 & 372 & 701 & $\begin{array}{l}\text { Represents total of all wastes (as-is) without } \\
\text { wastewater brine/solids, laundry items or total } \\
\text { normal/diarrheal feces (This could be considered to } \\
\text { be "Trash") }\end{array}$ \\
\hline $\begin{array}{l}\text { Feces only (normal and } \\
\text { diarrheal) }\end{array}$ & 130 & 103 & 140 & 99 & 74 & 113 & Represents total of normal and diarrheal feces (as-is) \\
\hline
\end{tabular}

Table 3. Moisture contents of various lunar outpost waste mixtures.

\begin{tabular}{|c|c|c|c|c|}
\hline $\begin{array}{l}\text { Moisture Content of Lunar Outpost } \\
\text { Mission Waste Mixtures (\%) }\end{array}$ & $\begin{array}{l}\% \text { Water } \\
\text { (Nominal) }\end{array}$ & $\begin{array}{l}\% \text { Water } \\
\text { (Minimum) }\end{array}$ & $\begin{array}{l}\text { \% Water } \\
\text { (Maximum) }\end{array}$ & Notes: \\
\hline Waste (no brine or brine solids) & 41.9 & 38.9 & 49.2 & $\begin{array}{l}\text { Represents total of all wastes (as-is) and contained } \\
\text { free water without brine products. }\end{array}$ \\
\hline $\begin{array}{l}\text { Waste (includes brine and brine } \\
\text { solids) }\end{array}$ & 50.5 & 54.2 & 54.6 & $\begin{array}{l}\text { Represents total of all wastes (as-is) including } \\
\text { wastewater brine. }\end{array}$ \\
\hline Waste (includes brine solids) & 39.9 & 36.2 & 47.2 & $\begin{array}{l}\text { Represents total of all wastes (as-is) without } \\
\text { wastewater brine, but with brine solids (Assumes brine } \\
\text { drying to } 100 \% \text { ) }\end{array}$ \\
\hline $\begin{array}{l}\text { Waste (no brine/solids, laundry } \\
\text { items) }\end{array}$ & 51.9 & 48.7 & 58.1 & $\begin{array}{l}\text { Represents total of all wastes (as-is) without } \\
\text { wastewater brine/solids or laundry items }\end{array}$ \\
\hline $\begin{array}{l}\text { Waste (no brine/solids, laundry, } \\
\text { feces) }\end{array}$ & 48.6 & 45.7 & 55.5 & $\begin{array}{l}\text { Represents total of all wastes (as-is) without } \\
\text { wastewater brine/solids, laundry items or total } \\
\text { normal/diarrheal feces (This could be considered to be } \\
\text { "Trash") }\end{array}$ \\
\hline Feces only (normal and diarrheal) & 76.4 & 72.3 & 80.9 & Represents total of normal and diarrheal feces (as-is) \\
\hline
\end{tabular}

Table 4. Production rates of various lunar outpost waste mixtures.

\begin{tabular}{|c|c|c|c|c|}
\hline $\begin{array}{l}\text { Lunar Outpost Waste } \\
\text { Crew Production Rates }\end{array}$ & $\begin{array}{l}\mathrm{kg} / \mathrm{CM}-\mathrm{D} \\
\text { (Nominal) }\end{array}$ & $\begin{array}{l}\mathrm{kg} / \mathrm{CM}-\mathrm{D} \\
\text { (Minimum) }\end{array}$ & $\begin{array}{l}\mathrm{kg} / \mathrm{CM}-\mathrm{D} \\
\text { (Maximum) }\end{array}$ & Notes: \\
\hline Waste (no brine or brine solids) & 1.49 & 1.26 & 1.84 & $\begin{array}{l}\text { Represents crew production of all wastes (as-is) and contained } \\
\text { free water without brine products. }\end{array}$ \\
\hline Waste (includes brine and brine solids) & 1.90 & 1.89 & 2.23 & $\begin{array}{l}\text { Represents crew production of all wastes (as-is) including } \\
\text { wastewater brine. }\end{array}$ \\
\hline Waste (includes brine solids) & 1.56 & 1.36 & 1.92 & $\begin{array}{l}\text { Represents crew production of all wastes (as-is) without } \\
\text { wastewater brine, but with brine solids (Assumes brine drying to } \\
100 \% \text { ) }\end{array}$ \\
\hline Waste (no brine/solids, laundry items) & 1.15 & 0.95 & 1.46 & $\begin{array}{l}\text { Represents crew production of all wastes (as-is) without } \\
\text { wastewater brine/solids or laundry items }\end{array}$ \\
\hline Waste (no brine/solids, laundry, feces) & 1.01 & 0.85 & 1.32 & $\begin{array}{l}\text { Represents crew production of all wastes (as-is) without } \\
\text { wastewater brine/solids, laundry items or total normal/diarrheal } \\
\text { feces (This could be considered to be "Trash") }\end{array}$ \\
\hline Feces only (normal and diarrheal) & 0.14 & 0.11 & 0.15 & Represents crew production of normal and diarrheal feces (as-is) \\
\hline $\begin{array}{l}\text { Wastewater Brine (urine,humidity cond., } \\
\text { hygiene) }\end{array}$ & 0.41 & 0.39 & 0.63 & $\begin{array}{l}\text { Represents crew production of wastewater brine including urine, } \\
\text { humidity condensate and hygiene brine sources }\end{array}$ \\
\hline
\end{tabular}

If a laundry system is utilized, clothes are not discarded, and the feces is handled separately, the waste production rate drops significantly $(1.01 \mathrm{~kg} / \mathrm{CM}$-day). Because this mixture does not contain feces, laundry items or brines, it is likely akin to the waste fraction typically referred to as trash in past missions. It should be noted that some clothes will eventually be discarded as they age beyond functional use. A value of $0.0373 \mathrm{~kg} / \mathrm{CM}-\mathrm{day}$ can be used as a clothes attrition rate with a laundry system for a 180-day mission, and can replace the laundry values used in this spreadsheet if a clothes washing system is implemented. ${ }^{1}$ 
The rate of feces production increases from $0.123 \mathrm{~kg} / \mathrm{CM}$-day to $0.140 \mathrm{~kg} / \mathrm{CM}$-day by including a single diarrheal event per month. Further definition is required to fully reflect the issues of fecal production rates, including the effect of high rates of EVA, which may increase food intake and concomitant feces generation.

Another waste source that was revealed to be a significant source of water was the urine contained in the MAGs used during EVA. The model currently assumes that $33 \%$ of a crewmember's total daily urine production is collected in the MAG per EVA event (EVA events were assumed to be of long duration, 7-8 hrs). The 33\% value represents approximately $0.515 \mathrm{~kg} / \mathrm{CM}$-day, which is a significant portion of the overall waste produced per day. This is an important issue when evaluating the potential for water recovery from wastes, as the MAGs would likely need to be stored in the lunar rovers and processed at the core habitat to recover that water. The assumed rate of EVA used in this model ( $22.3 \mathrm{hrs}$ EVA per day) is substantially higher than the value used in another analysis by the ELS Systems Integration and Modeling Analysis (SIMA) group (7.3 hrs EVA per day). Further research is required to determine average EVA MAG contents during various EVA event durations.

One area that remains undefined and is not addressed in this model is the issue of packaging used for items other than food. There is the potential that consumable items may come individually wrapped in plastic, paper or in foam. While paper and plastic (film) can readily be incorporated with most other wastes, the foam that often protects shipped hardware can be stiff and bulky. It must be decided where such wastes will be processed and/or stored. Because they are unlikely to contain any significant water, these types of additional wastes are unlikely to serve as a significant water source/sink, and the exclusion of them from this model will affect only the waste mass estimates. Further definition is required.

\section{Future Waste Model Efforts}

This effort focused on defining the major waste model needs for waste type, amount, and water content. In order to increase the utility of the model to serve more refined analyses, more data are required. With regards to water content, the production of water via mineralization should be examined in addition to the potential to recover free water.

In addition to total waste quantities produced, the potential patterns of generation (e.g., frequent vs. intermittent) also require examination. Of particular interest is the potential for large amounts of stored waste to be returned from long Lunar Electric Rover (LER) excursions. This waste could present a processing challenge to WMS processors, particularly if all crew are away from the core habitat for extended periods. Unless wastes can be processed autonomously in a continuous system, oversized processors would need to be developed in order to process wastes while the core habitat is manned. This could significantly affect WMS operations. Therefore, increased detail is required on the EVA schedule, including duration, number of events and the availability of crew to process wastes.

Additionally, the issue of waste mixtures will need to be studied. For example, certain wastes may be generated in combination and in particular proportions, and may strongly influence processing possibilities. Certain waste streams may therefore be addressed as mixtures rather than as individual components. In addition, waste segregation can be examined with respect to its potential effect on general waste management and water recovery goals. Segregation may be required to enable certain waste processing needs, such as potentially segregating dry wastes from wet wastes to decrease waste drying operations. The potential for waste variability both during a mission and among mission types will also need to be assessed, as this can also influence the types of waste processors that can be utilized.

Another effort that requires consideration is the need to develop and maintain a system that can track the "waste" materials generated by the various mission sub-systems. This could be considered to be a "waste catalogue" that allows each sub-system to identify the materials/parts of that system to be discarded. This could include nominal (predicted) process products and expendables. The catalogue would best be maintained as a web-based tool that allows real-time updating from authorized personnel from each of the relevant sub-systems. This information would allow the waste sub-system to optimize their research and technology development program to best meet the needs of the mission. Additionally, this information would allow the WMS element to provide feedback to other subsystems regarding certain problematic wastes. This provides an opportunity for material substitution to be investigated in a timely fashion. It is expected that future efforts on waste model development will occur as time and opportunity allow. 


\section{Key Influences on the Water Balance}

In addition to wastewater recovery efficiency, humidity condensate management, and solid waste processing, the water balance is strongly affected by the scavenging of water from the Lunar Lander, the amount of Extra Vehicular Activity (EVA) conducted, the amount of water in the food, and the utility of excess water. The following sections address these subjects.

\section{A. Altair Lunar Lander Residual Fuels as a Potential Water Source}

\section{Altair System Description.}

The spacecraft that has been under development to enable humans to land on the surface of the moon is termed Altair. The Altair lunar lander is comprised of a Descent Module and an Ascent Module. The primary task of the Descent Module is to land the Altair system on the moon and provide power for the descent via a $4 \mathrm{~kW}$ fuel cell. The descent module uses a hydrogen/oxygen rocket motor. The Ascent Module is used to launch astronauts into lunar orbit for rendezvous with the Orion spacecraft after completing the lunar surface mission. The Ascent Module detaches from the Descent Module upon launch from the lunar surface leaving behind a significant quantity of hydrogen and oxygen rocket fuel in the Descent Module propulsion system. The fuel cell system remains on the Descent Module. A current mission option is to use the Descent Module's fuel cell to convert the remaining rocket fuel into water.

The fuel remaining on the Descent Module is in the form of residuals and unused fuel necessary to provide a safety margin for landing. Residual fuel is defined as fuel that cannot be extracted for use by the lander rocket motor in order to prevent fuel feed pump cavitation or accelerated heating of the fuel. Residual fuel will provide a relatively predictable quantity of fuel that will be available for production of water or for other uses. The amount of residual fuel that will be available for recovery for life support purposes cannot be known until the Altair Lander Descent Module propulsion system design has been finalized.

In addition to the residual fuel is the unused reserve fuel that provides a safety margin to allow for variations in landing efficiency. The quantity of reserve fuel remaining after landing is by nature unpredictable and therefore cannot be considered a reliable potential water source for mission planning purposes.

\section{Fuel Scavenging Studies}

Previous studies have been performed to determine the feasibility of recovering the Altair Lunar Lander fuel residuals for water production or other uses. ${ }^{4,5}$ These studies describe the thermal conditions in the tanks that limit how much residual fuel can actually be reclaimed for use for the lander fuel cells and life support after touchdown. The current assumption is that the amount of residual fuel remaining in the hydrogen and oxygen tanks will be 3\% by volume although residuals of $2 \%$ have been considered. ${ }^{5}$ The current lunar lander descent stage concept consists of four hydrogen tanks with a volume of 17.0 cubic meters each and four oxygen tanks with a volume of 5.44 cubic meters each. Based on an assumption of $3 \%$ residuals by volume, the total mass of residual fuel in the form of liquid and vapor remaining in the tanks after touchdown is $43.1 \mathrm{~kg}$ of hydrogen per tank and $179 \mathrm{~kg}$ oxygen per tank prior to any venting or scavenging. The scavenging study estimates that as much as $676 \mathrm{~kg}$ of water can be produced from the residuals in a lander based on the stoichiometric ratio of hydrogen and oxygen remaining in the tanks for a seven day lunar outpost mission. ${ }^{4}$

Both the hydrogen and oxygen tanks contain helium that is used to pressurize the tanks for operation with the descent stage rocket motors. In order to allow the use of the fuel cell for water production helium must be purged from both the hydrogen and oxygen fuel. The scavenging study suggests that $1.7 \mathrm{~kg}$ of hydrogen and $2.6 \mathrm{~kg}$ of oxygen will be lost per tank after purging enough helium to allow proper operation of the fuel cells. ${ }^{4}$

In addition to the venting losses from purging helium are significant venting losses that result from maintaining the proper operating pressure for the hydrogen feed into the fuel cell system.

The scavenging study describes a thermal analysis of the tanks to determine venting losses but did not include this data in the estimates of residual fuel available to produce water. The reason that no venting losses were considered in the estimation of the total possible water that could be recovered was that it was assumed that some means of preventing venting losses would be incorporated into the final scavenging solution. ${ }^{4}$

It is possible that no water production can occur after a short sortie mission because the fuel cell may be destroyed by ascent module liftoff. However, it is assumed that for a lunar outpost mission, the astronauts leaving the lunar surface will not do so before all residual fuel has been scavenged.

Additional equipment beyond what is currently envisioned in the current lunar surface systems design analysis will need to be provided to allow water recovery. If venting losses are to be prevented, the equivalent system mass 
(ESM - the cost of mass, volume, energy, and crew time is all converted to a single cost factor expressed as equivalent mass) of the additional equipment will increase further.

\section{Application of Fuel Scavenging to ELS}

Lunar location factors greatly affect the venting loss rates due to differing thermal conditions. The two extremes are a polar mission and an equatorial mission. During an equatorial mission the lander fuel tanks will see higher thermal loads from the lunar surface in addition to the sun when compared to a polar mission. The higher thermal load experienced during an equatorial mission will result in increased venting rates and a decrease in the amount of water that can be produced from residual fuel when compared to a polar mission.

Figure 1 is for a lunar equatorial mission and shows the adjustment made to account for helium purging losses. The curve titled "Mass in tank" indicates the length of time that the required feed rate to the fuel cell can be maintained without including the helium purge. The "Mass in tank" curve shows the effects of thermally induced losses that occur from preventing the hydrogen tanks from exceeding design pressure. The curve titled "Mass in tank including venting losses" takes into account a lower initial quantity of hydrogen that results from purging helium to a level that allows acceptable performance from the fuel cells. After 14.5 days there is insufficient hydrogen in the tanks to produce the required operating pressure and hydrogen feed rate needed to allow the fuel cells to continue to function.

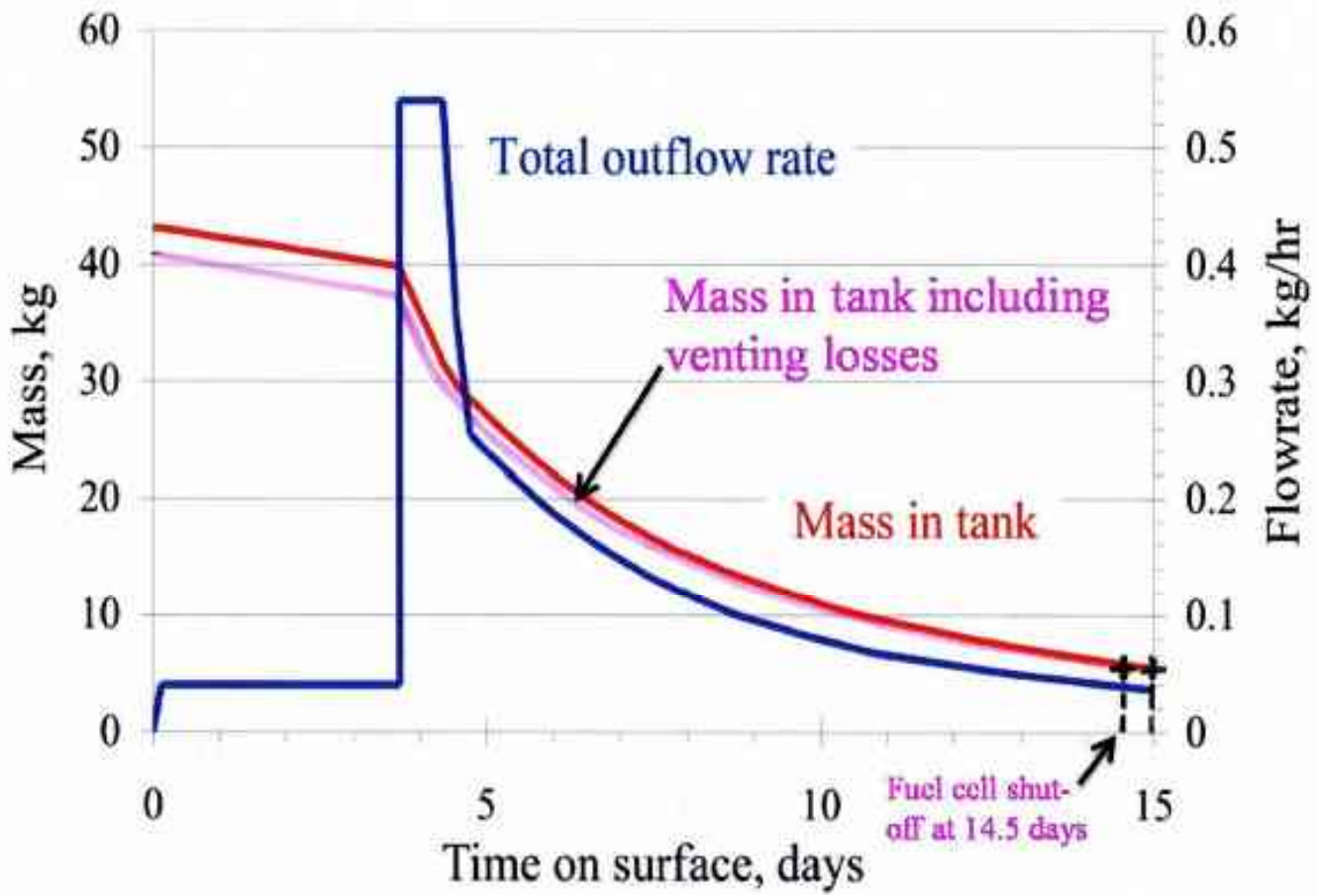

Figure 1. Comparison of hydrogen mass in tanks when helium purging losses are accounted for at an equatorial location (Modified from Linne et al. $2009{ }^{4}$ ).

Fuel cell water production rates are linear. Table 5 below shows the amount of water remaining for the lunar outpost after taking into account venting losses and also the effect of location on the amount of water consumed for Altair operations for a one-day outpost mission. The analysis from the Altair Consumables management paper and the Scavenging paper assume a suit cooling loss of $1.8 \mathrm{~kg}$ of water per crew member per 8 hour EVA. ${ }^{4,5}$ Using the water consumption rate of current technology, actual EVA suit cooling losses at the equator will be as high as $7.7 \mathrm{~kg}$ per crew member per 8 hour EVA. ${ }^{6}$

Equation 1 below was used in Table 5 to determine the amount of water that can be produced per tank while sufficient feed rates to the fuel cell can be maintained before including the effects of location on EVA suit cooling losses.

Equation 1:

$$
\mathrm{H}_{2} \mathrm{O} \text { per tank }=0.376 \frac{\mathrm{kg} \mathrm{H}_{2}}{\operatorname{tank} \bullet \text { hour }} \bullet(14.5-1) \text { days } \bullet 24 \frac{\text { hours }}{\text { day }} \bullet \frac{18.015}{2 \bullet 1.0079}=108.9 \mathrm{~kg}
$$


Equation 2 below was used in Table 5 and factors in the effect of location factors on EVA water losses, Altair mission consumption, and the total number of tanks to arrive at the final quantity of water that can be made available for the lunar outpost. The EVA suit factor is the total quantity of water lost due to EVA suit cooling for a fourperson crew at the equator. The difference between the EVA suit factor and the amount of water lost due to an EVA cooling rate for $1.8 \mathrm{~kg}$ per crew member per 8 hour EVA for a four person crew is subtracted from the amount determined in Equation 1 to provide the total water available for outpost under the specified conditions.

Equation 2:

$$
\text { Total } \mathrm{H}_{2} \mathrm{O}=\mathrm{H}_{2} \mathrm{O} \text { per tank } \bullet \frac{\mathrm{kg} \mathrm{H}_{2}}{\operatorname{tank}} \bullet \text { total tanks }-(\text { EVA suit factor }-4 \bullet 1.8)=412 \mathrm{~kg}
$$

Table 5. Altair residual fuel scavenging parameters for an equatorial location starting with $3 \%$ residuals

\begin{tabular}{|l|c|c|}
\hline \multicolumn{1}{|l}{} & $\begin{array}{c}\text { Mass per tank (except where } \\
\text { noted), kg }\end{array}$ \\
\hline Total mass before purging helium & $\begin{array}{c}\mathbf{H}_{2} \text { (except } \\
\text { where noted) }\end{array}$ & $\begin{array}{c}\mathbf{O}_{2} \text { (except } \\
\text { where noted) }\end{array}$ \\
\hline Mass loss from purging helium prior to scavenging & 43.1 & 179 \\
\hline Mass available for scavenging for outpost before pressure control venting & 1.7 & 0.85 \\
\hline Duration of water production using available gas (days) & 41.4 & 178.2 \\
\hline Duration that Altair consumes product produced by fuel cells (days) & 14.5 & not calculated \\
\hline Quantity of unusable gas remaining in tanks & 1 & 1 \\
\hline Fuel cell consumption fuel component consumption rate per tank per hour & 5 & 20 \\
\hline Mass of water that can be produced per tank & 0.0376 & 0.37 \\
\hline Total number of tanks & 108.9 & 168.2 \\
\hline EVA suit factor (water consumed by crew of 4 during 1 day of Altair Ops) kg & 4 & 4 \\
\hline Total water available for outpost from all tanks & 30.8 & 30.8 \\
\hline Gas remaining due to unavailable gas to satisfy stoichiometric ratio (all tanks) & $\mathbf{4 1 2}$ & 649 \\
\hline
\end{tabular}

Table 6. Altair residual fuel scavenging parameters for a polar location starting with $3 \%$ residuals

\begin{tabular}{|l|c|c|}
\hline \multicolumn{1}{|l|}{} & $\begin{array}{c}\text { Mass per tank (except where } \\
\text { noted), kg }\end{array}$ \\
\hline Total mass before purging helium & $\begin{array}{c}\text { H2 (except } \\
\text { where noted) }\end{array}$ & $\begin{array}{c}\text { O2 (except } \\
\text { where noted) }\end{array}$ \\
\hline Mass loss from purging helium prior to scavenging & 43.1 & 179 \\
\hline Mass available for scavenging for outpost before pressure control venting & 1.7 & 0.85 \\
\hline Duration of water production using available gas (days) & 41.4 & 178.2 \\
\hline Duration that Altair consumes product produced by fuel cells (days) & 18.5 & not calculated \\
\hline Quantity of unusable gas remaining in tanks & 1 & 1 \\
\hline Fuel cell consumption fuel component consumption rate per tank per hour & 8 to 9 & 20 \\
\hline Mass of water that can be produced per tank & 0.0376 & 0.37 \\
\hline Total number of tanks & 141.1 & 168.2 \\
\hline EVA suit factor (mass of water consumed) & 4 & 4 \\
\hline \hline Total water available for outpost from all tanks & 10.8 & 10.8 \\
\hline \hline Gas remaining due to unavailable gas to satisfy stoichiometric ratio (all tanks) & $\mathbf{5 6 1}$ & 669 \\
\hline
\end{tabular}

Due to the high cost of delivering mass to the moon there is great impetus for reducing launch mass. Current design analyses have considered improving the efficiency of the Altair lunar lander by reducing the amount of residual fuel remaining on the lunar lander descent stage after touchdown to $2 \%{ }^{5}$

Starting with $2 \%$ residuals reduces the fuel cell operation time to 11.5 days. Using the same equations and factors as defined in Table 1 and Equations 1 and 2, the total amount of water available for a lunar outpost at an equatorial mission starting with $2 \%$ residuals is $315 \mathrm{~kg}$.

If an outpost is located at a lunar pole the amount of hydrogen venting losses occurring during scavenging are reduced. After adjusting the value of the mass during Altair operations from seven days to one day, the total amount 
of water that can be produced from all four tanks is $676 \mathrm{~kg}$ based on the stoichiometric balance of available fuels with oxygen as the limiting fact. As mentioned previously this value doesn't take into account venting losses.

Using Table 6 and Equations 1 and 2, the total amount of water available for a lunar outpost at a polar location starting with $3 \%$ residuals is $561 \mathrm{~kg}$.

This includes an EVA suit factor of $10.8 \mathrm{~kg}$ for a four-person crew for one day. A cooling loss of $2.7 \mathrm{~kg}$ per crewmember per 8 hour EVA is expected when averaged between an 88 degree latitude location and a permanently shadowed crater. ${ }^{6}$

\section{Summary of Potential Water from Scavenging}

Table 7 below provides a summary of the amount of water that can be scavenged after taking into account venting losses.

Table 7. Summary of quantity of water that can be scavenged from both equatorial and polar locations

\begin{tabular}{|l|c|}
\hline Parameters & Water (kg) \\
\hline Equatorial location, 3\% residuals & 412 \\
\hline Equatorial location, 2\% residuals & 315 \\
\hline Polar location, 3\% residuals & 561 \\
\hline Polar location, 2\% residuals & 432 \\
\hline
\end{tabular}

\section{Fuel Scavenging ESM Estimates}

The scavenging of residual fuels will require equipment beyond what is currently envisioned in the Altair system. The equipment will consist of receptacles to contain the water product such as a solid or flexible tank, ${ }^{4}$ fluid lines to transport the water product from the fuel cell to the receptacles, valves and connectors, a pump, and other ancillary equipment.

A likely concept for receiving and transporting the water product produced from the scavenged residuals would be a trailer containing a water tank, some sort of thermal control, a pump and possibly an energy storage source to provide power to the pump and thermal control system when the trailer is not receiving power from the Altair Descent Module or the Lunar Outpost.

The use of the $4 \mathrm{~kW}$ fuel cell onboard the lander controls the maximum rate of water production, which in turn results in venting of hydrogen due to the many days required to convert the hydrogen and oxygen to water. ${ }^{5}$ A larger or additional fuel cell could be used to avoid the venting loss issue by increasing the water production rate such that all hydrogen is processed before tank pressures become high enough to require venting.

Current concepts for fuel scavenging include the use of a $4.0 \mathrm{~kW}$ fuel cell that is part of the Altair Descent Module. Using the heat of reaction of hydrogen and oxygen to produce water and using the water production rate of $1.32 \mathrm{~kg} / \mathrm{hr},{ }^{4}$ the total rate of heat generated would be approximately $5.8 \mathrm{~kW}$. The conversion efficiency of the system is approximately $70 \%$. The current radiator system envisioned for Altair can reject heat at a rate of up to $6 \mathrm{~kW}$. The Altair radiator system only provides a 5\% margin over the total possible heat that can be generated by the specified $4 \mathrm{~kW}$ fuel cell operating at $70 \%$ efficiency.

Calculations indicate that a hydrogen feed rate of approximately $0.45 \mathrm{~kg}$ per hour or three times greater than the feed rate of the fuel cell currently envisioned for Altair must be used to prevent hydrogen venting losses at the lunar pole. This equates to a fuel cell power rating of roughly $12 \mathrm{~kW}$. With an energy conversion efficiency of approximately $70 \%$, energy must be removed at a maximum rate of $18 \mathrm{~kW}$ (assuming only $5 \%$ safety margin on radiator) via usage by some currently undefined system or bled off by a radiator. This would require a radiator capable of removing energy at a rate of up to $12 \mathrm{~kW}$ more than Altair's $6 \mathrm{~kW}$ radiator system. Unless there is a use for the extra power, a larger radiator must be provided.

To prevent hydrogen venting losses at the moon's equator, the fuel cell feed rate must be increased to $0.60 \mathrm{~kg}$ per hour or four times greater than the currently envisioned system. This equates to $16 \mathrm{~kW}$ of usable power and would require energy to be removed from the system at a rate of $24 \mathrm{~kW}$. This would require a radiator capable of removing heat at a rate of up to $18 \mathrm{~kW}$ more than Altair's $6 \mathrm{~kW}$ radiator system. Thus an even larger radiator may be necessary at the equator.

Two options exist for a stand-alone water scavenging system. One possible solution is to incorporate the additional fuel cell and associated power distribution and thermal management systems into the water collection and transport trailer. The second solution is to incorporate a fuel cell and radiator system on the water scavenging trailer that is capable of recovering all the residuals without the need to use the descent stage fuel cell system. Both 
solutions would provide a viable alternative should incorporation of a larger fuel cell and radiator system into the Altair descent stage present a problem.

The most likely stand alone water scavenging system designed to recover all hydrogen residuals at a polar location would require an $8 \mathrm{~kW}$ fuel cell and a radiator system capable of radiating heat at a rate of at least $12 \mathrm{~kW}$ in addition to the Altair fuel cell and radiator. The same solution for an equatorial system would require a $12 \mathrm{~kW}$ fuel cell and an $18 \mathrm{~kW}$ radiator.

Below shows the ESM comparison of the additional hardware required to recover all residuals and water gained versus that of the nominal system that uses only the descent stage fuel cell. The fuel cell mass and volume are based on the space shuttle fuel cell. The space shuttle fuel cell has a constant output of $12 \mathrm{~kW}$ and has a mass of $116 \mathrm{~kg}$. The volume of the space shuttle fuel cell is $0.16 \mathrm{~m}^{3}$.

Crew time estimates for scavenging operations including hook up, travel between the outpost and the lander, detachment of the water transport trailer, and other associated operations range between 4 to 30 hours per lander assuming efficient operation. Once a scavenging system is better designed, a better estimate of crew time can be made that incorporates the complexities of operation including fuel cell valve switching sequences, fuel cell re-start processes, etc.

Table 8 below shows the ESM of a trailer system designed for a polar location. The system includes an additional $8 \mathrm{~kW}$ fuel cell with a conversion efficiency of $70 \%$ that provides $12 \mathrm{~kW}$ of thermal rejection via its own radiator system. Table 4 assumes that the outpost is located $8 \mathrm{~km}$ from the Altair landing site and that the rover average speed is $8 \mathrm{kph}$.

Table 8. ESM of a trailer system designed to prevent hydrogen venting losses at the lunar pole

\begin{tabular}{|l|c|c|c|c|c|c|}
\hline Parameter & $\begin{array}{c}\text { Equivalency } \\
\text { Factor }\end{array}$ & $\begin{array}{c}\text { Equivalency } \\
\text { Factor Units }\end{array}$ & $\begin{array}{c}\text { Equipment } \\
\text { Properties }\end{array}$ & $\begin{array}{c}\text { Equipment } \\
\text { Properties } \\
\text { Units }\end{array}$ & $\begin{array}{c}\text { Parameter } \\
\text { ESM value }\end{array}$ & $\begin{array}{c}* \\
\text { Notes }\end{array}$ \\
\hline \hline Mass & 1.0 & $\mathrm{~kg} / \mathrm{kg}$ & 797.4 & $\mathrm{~kg}$ & 797 & 1 \\
\hline Volume & 9.2 & $\mathrm{~kg} / \mathrm{m}^{3}$ & 15.2 & $\mathrm{~m}^{3}$ & 139 & 2 \\
\hline Power & 72.9 & $\mathrm{~kg} / \mathrm{kW}$ & $\mathrm{na}$ & $\mathrm{na}$ & $\mathrm{na}$ & 3 \\
\hline Thermal & 48.5 & $\mathrm{~kg} / \mathrm{kW}$ & 12 & $\mathrm{~kW}$ & 582 & 4 \\
\hline Crew Time & 1.5 & $\mathrm{~kg} / \mathrm{cm}-\mathrm{h}$ - & 8.4 & $\mathrm{hrs}$ & 12.6 & 5 \\
\cline { 3 - 7 } & & & \multicolumn{2}{c}{ Total ESM $=$} & $\mathbf{1 5 3 1}$ & 6 \\
\cline { 4 - 7 }
\end{tabular}

* Notes:

1. Includes mass of $12 \mathrm{~kW}$ fuel cell.

2. Includes volume of $12 \mathrm{~kW}$ fuel cell. Assumed unpressurized volume. BVAD values for lunar surface. Not known if fuel cell requires pressurized volume.

3. Fuel cell provides its own power.

4. Radiator needed in addition to Altair $6 \mathrm{~kW}$ radiator.

5. Assumes transport time to and from landing site $8 \mathrm{~km}$ from outpost at $8 \mathrm{kph}$. Operation times include trailer retrieval, hook up and removal of system from Altair, to LER, then to the outpost for a single tank. Times also include valve switching, fuel cell stop and restart times, etc. Actual crew times may be significantly higher.

6. Total ESM of trailer with additional $8 \mathrm{~kW}$ fuel cell and associated $12 \mathrm{~kW}$ radiator system.

If the trailer system does not include the additional fuel cell or radiator system, then the total ESM drops to about $870 \mathrm{~kg}$.

Table 9 below provides a comparison of the ESM to implement the no venting loss and the venting loss solution. The breakeven time is calculated based on the minimum time between Altair landings provided via personal communication from the NASA Lunar Surface Systems (LSS) Environmental Control and Life Support Systems (ECLSS) Manager.

Table 9. Breakeven times for No Venting Loss and Venting Loss water scavenging at a polar location

\begin{tabular}{|l|c|c|c|c|}
\hline \multicolumn{1}{|c|}{ Scenario } & $\begin{array}{c}\text { Equipment } \\
\text { ESM (kg) }\end{array}$ & $\begin{array}{c}\text { Water Savings } \\
\text { per Lander (kg) }\end{array}$ & $\begin{array}{c}\text { Lander Schedule } \\
\text { (days) }\end{array}$ & $\begin{array}{c}\text { Breakeven Time } \\
\text { (days) }\end{array}$ \\
\hline No venting loss solution & 1531 & 676 & 120 & 272 \\
\hline Venting losses allowed & 870 & 561 & 120 & 186 \\
\hline
\end{tabular}


Table 10 below shows the total water scavenged by both the No Venting Loss and Venting Loss Allowed residual fuel scavenging systems over the projected fully matured outpost operation period. The system that allows venting losses has a significantly lower breakeven time but over the 1440 day period the No Venting Loss system produces $719 \mathrm{~kg}$ more water.

The ESM figures provided thus far only evaluate a few scenarios and possible solutions. A more thorough ESM analysis should be performed after more detailed information on lunar surface systems and concepts of operation become available.

Table 10. Comparison of total benefit of No Venting Loss vs. Venting Loss Allowed in scavenging systems over mission lifetime.

\begin{tabular}{|c|c|c|c|c|}
\hline $\begin{array}{c}\text { Mission } \\
\text { duration } \\
\text { (days) }\end{array}$ & $\begin{array}{l}\text { No Venting Loss } \\
\text { solution ESM } \\
\text { and water mass } \\
\text { balance (kg) }\end{array}$ & $\begin{array}{l}\text { Venting Loss } \\
\text { Allowed } \\
\text { solution ESM } \\
\text { and water mass } \\
\text { balance (kg) }\end{array}$ & $\begin{array}{l}\text { Mass difference of } \\
\text { No Venting Loss vs } \\
\text { Venting Loss } \\
\text { Allowed solution } \\
\text { (kg) }\end{array}$ & Notes \\
\hline 0 & -1531 & -870 & -661 & $\begin{array}{l}\text { This row gives the equipment ESM } \\
\text { before any water savings }\end{array}$ \\
\hline 120 & -855 & -309 & -546 & \\
\hline 240 & -179 & 252 & -431 & \\
\hline 360 & 497 & 813 & -316 & \\
\hline 480 & 1173 & 1374 & -201 & \\
\hline 600 & 1849 & 1935 & -86 & \\
\hline 720 & 2525 & 2496 & 29 & \\
\hline 840 & 3201 & 3057 & 144 & \\
\hline 960 & 3877 & 3618 & 259 & \\
\hline 1080 & 4553 & 4179 & 374 & \\
\hline 1200 & 5229 & 4740 & 489 & \\
\hline 1320 & 5905 & 5301 & 604 & \\
\hline 1440 & 6581 & 5862 & 719 & $\begin{array}{l}\text { The ESM and water mass balance } \\
\text { columns give the water } \\
\text { deficit/surplus. The comparison } \\
\text { column shows difference in total } \\
\text { water recovered from both systems }\end{array}$ \\
\hline
\end{tabular}

\section{Uncertainty}

Considerable uncertainty exists as to how much residual can be scavenged for life support purposes. A combination of factors affects the total amount that may be available and are currently to be determined. Undecided factors including Altair lander mission schedule, Altair propulsion system residuals quantity, venting losses, location factors, EVA suit technology, scavenging operations time and equipment ESM all have a large effect on the final quantity of scavengable water and cost of the associated system.

Estimates of water that can be scavenged at a polar site range from 432 to $676 \mathrm{~kg}$ per lander. If the outpost is located at the lunar equator the amount of recoverable water ranges from 315 to $676 \mathrm{~kg}$ or a variation of $53 \%$ per lander.

Other factors affecting the amount of water recovered include the time between Altair landing (105 to120 days have been recently considered), and the percent residuals in the Altair tanks. The average daily amount of water made available from residual fuel scavenging varies from $2.6 \mathrm{~kg}$ water per day at an equatorial location with $2 \%$ residuals and a lander delivery schedule of 120 days to $6.4 \mathrm{~kg}$ water per day at a lunar pole with $3 \%$ starting residuals, zero venting losses, and a lander delivery schedule of 105 days.

\section{Conclusions for Water Scavenging}

Scavenging of residual fuels is a potentially viable means of adding robustness to both the lunar sortie and lunar outpost missions. At this stage in the development of the Altair lunar lander and the lunar outpost operations concepts, the total amount of water that can be made available from scavenging residuals and reserve propellant is very uncertain. Further work needs to be performed to ascertain the amount of water available for mission planning and hardware development decisions. 


\section{B. Water Use for Extravehicular Activity}

Currently, the single largest nominal water loss mechanism anticipated during lunar surface missions is through EVA suit thermal regulation. Past and current Extravehicular Activity (EVA) Portable Life Support Systems (PLSSs) for space suits require significant amounts of gases and water to be vented to vacuum. The principal means of water loss during a long-duration lunar mission is through water sublimation for cooling space suits. ${ }^{7}$ The actual amount of water lost during EVA operations depends on numerous factors that include: the frequency and duration of EVA events, the human activity (metabolic) rate, the type of thermal regulation system, and the thermal environment when in use (as affected by mission location).

The only suits utilized on the moon to date were the suits used during the Apollo missions. These suits used water ice sublimators for cooling the liquid cooling and ventilation garment (LCVG), which is the garment that the crew wore to provide circulation of cooling water and suction return of gas from the hands and feet. The LCVG both maintained proper body temperatures and provided air circulation to remove $\mathrm{CO}_{2}$ and water vapor. The water vapor from respiration and perspiration emitted in the suit was condensed, and was reused in the water ice sublimator. Therefore, the water used by the ice sublimators was a combination of supplied water and recovered water. A 7-hour EVA using this suit required about $3.50 \mathrm{~kg}$ to $5.40 \mathrm{~kg}$ of cooling water. ${ }^{8}$ Water that was not used during an EVA was returned with the suit. The entire suit had a mass of $88.4 \mathrm{~kg}$. ${ }^{9}$

Studies are currently investigating the anticipated water usage for suit cooling for future lunar EVA operations. ${ }^{6,7}$ These studies show that the location of the mission, as well as the time of day that EVA is conducted, will exert a strong effect on total water utilization. For example, based on predicted metabolic and suit equipment heat loads, the highest water use values anticipated would occur at noon on the lunar equator, and is predicted to use an average of $4.5 \mathrm{~kg} / 7 \mathrm{hr}$ EVA (low of 3.1 and high of $6.7 \mathrm{~kg} / 7 \mathrm{hr}$ EVA). In contrast, a permanently shadowed area at one of the lunar poles is only expected to use $0.2 \mathrm{~kg} \mathrm{H}_{2} \mathrm{O} / 7 \mathrm{hr}$ EVA (low of 0 and high of $2.4 \mathrm{~kg} \mathrm{H}_{2} \mathrm{O} / 7 \mathrm{hr} \mathrm{EVA}$ ).

The baseline heat rejection technology selected for development for the Constellation lunar suit is termed the Space Suit Water Membrane Evaporator (SWME). The hollow fiber SWME design is being considered for use in the Constellation Space Suit Element (CSSE) Portable Life Support Subsystem (PLSS). The system will provide cooling to the LCVG thermal loop through water evaporation to space vacuum. Current values that are being utilized for the spacesuit water membrane evaporator (SWME) cooling system under development for lunar missions are estimated at $1.8-2.1 \mathrm{~kg} \mathrm{H} 2 \mathrm{O} / 7 \mathrm{hr}$ EVA for the a South pole mission.

Alternate suit types are being investigated for future use that can greatly decrease or eliminate water use for thermal regulation. One current alternative under development is the regenerable fusible heat sink concept. This operates by freezing a liquid into solid phase on a heat sink prior to use. The melting of the solid to liquid phase provides cooling to the heat sink, which can be connected to the LCVG. Water is a favorable choice in that it has a high heat of melting and fusion, is non-toxic and readily available. The heat absorbed by melting water is 6.7 times less than that of water ice sublimation; therefore that amount of extra water is required to be carried within the PLSS for an equivalent EVA period. Adding this amount of mass to the suit could create operational difficulties. One option is to utilize smaller interchangeable heat sinks that could be stored within the rover or at the worksite. If successful designs can be created, fusible heat sink technology has the potential to eliminate water use for suit cooling.

The second alternative suit design uses radiators to reject heat from the suit. The coolant loop from the LCVG can be routed to the radiator, which then cools the liquid. Calculations indicate that radiators can often be satisfactory for thermal environments found on the poles, but that they are not viable in more moderate thermal environments. ${ }^{6}$ The radiators themselves can gain a significant amount of heat from sunlight, and may require sophisticated systems to ensure that some portions of the radiator panels face away from the sun at all times. The addition of heat pumps to radiator systems increases the cooling capacity and makes radiators a more feasible option for many lunar locations. It has been calculated that a heat pump radiator system is capable of stand-alone operation at all locations except the case of the equator at noon. ${ }^{6}$ It is also possible that a water sublimator can serve as a backup to a radiator/heat pump, which would allow this combination to work in all locations, while dramatically reducing the overall amount of water loss to sublimation.

An obvious critical factor regarding the potential water loss from EVA is the total duration of EVA operations. Given the preliminary nature of future missions, the scheduling of EVA is still uncertain. Regardless, the current desire for EVA is extensive, and may range from approximately $50-80 \%$ of crew time away from the core habitats in the pressurized rovers. Recent estimates of EVA activity from rovers have ranged from 7.3 EVA hr/day to 22.3 EVA hr/day. From this it is clear that the actual amount of EVA operations is not fully defined, and this uncertainty can strongly influence the overall water balance. In this example, over a 180 day mission segment, this results in a $709 \mathrm{~kg}$ difference in water usage (assuming a water loss rate of $2.1 \mathrm{~kg} / 8 \mathrm{hr}$ EVA) between the two EVA scenarios. 
Another issue that may affect EVA water use is the method of $\mathrm{CO}_{2}$ collection within the suit. The Apollo suit utilized expendable $\mathrm{LiOH}$ canisters that removed $\mathrm{CO}_{2}$. The current Shuttle/ISS suit utilizes a regenerable silver oxide sorbent canister known as "MetOx" to remove $\mathrm{CO}_{2}$. The canister can be used for 8 hours or more and is thermally regenerated in the spacecraft to allow for reuse. Both the Apollo and ISS systems allow water vapor to pass through without substantial absorption in the canister, and the water can therefore be condensed and utilized in the ice sublimation system.

Alternate regenerable $\mathrm{CO}_{2}$ removal systems are under development for the CSSE PLSS in order to decrease consumables and potentially increase EVA duration capacity. One includes the use of a rapid cycling amine (RCA) system that simultaneously captures both water vapor and $\mathrm{CO}_{2}$. This metal oxide sorbent two-bed system regenerates one bed to space vacuum while the other is adsorbing. Therefore, some water is lost along with the $\mathrm{CO}_{2}$ irrespective of the suit cooling system employed. ${ }^{10}$ As the RCA system does not serve to cool the suit, any water lost via regeneration would be in addition to any water losses in the cooling system.

In summary, the losses of water through EVA may range dramatically in future lunar surface missions. Location factors, the amount of EVA performed and PLSS designs are currently under consideration, and could result in either large water losses or practically none.

\section{Water in the Food}

\section{Introduction}

Water content of food for space exploration has varied, depending upon the mission scenario. In early space flights, astronauts were provided bite-sized food that, though nutritionally adequate had low acceptability by astronauts. Subsequently, foods were upgraded to a more earth-like situation, but this occurred with penalties in mass, power and volume. ${ }^{11}$ For missions of relatively short duration the penalties are perhaps justified on the grounds of providing astronauts a familiar style of living. With longer duration missions planned for lunar habitats and with increasing pressure for lowering mission costs, there is a need to revisit methods for lowering mass, power and volume penalties. Typically, food is only about $5 \%$ of the total payload on a shuttle. However, it still offers an opportunity to reduce payload, since supplying dehydrated food will substantially reduce volume and mass. The same cannot be said for other consumables such as clothing. Dehydrated food generally has longer shelf life and can be easily rehydrated prior to use. The water for the rehydration process can be provided from a water recovery system. Recent progress made in recovery of water from urine, humidity condensate, hygiene water and solid wastes have shown great promise and may justify efforts to supply dehydrated food to reduce mass and consequently mission costs.

\section{Current Status of Water Content in Food}

Shuttle food has generally had less water content than food on International Space Station because water is readily available as a by-product of the fuel cells that provide the Shuttle's power supply. ${ }^{12}$ Typically, shuttle food contains $50 \%$ moisture and the beverages are made reconstituted from dried powder. ${ }^{13}$ The food supplied on ISS has generally been supplied fully hydrated with no need for rehydration of food or reconstitution of beverages. Recently, with the installation of the water recycling system (WRS) on ISS, it is estimated that the ISS water recycling unit could produce about 18 liters of potable water from the urine, flush water and humidity condensate from a 6-person crew. This raises the possibility of supplying the ISS crew with dehydrated food and beverage powder that can be used in combination with the recycled water. In the case of a Lunar habitat, there is likely to be more water available since it is likely that in addition to processing urine, flush water and humidity condensate, water may also be made available through processing of wastes, brines, hygiene water and possibly extracting water from Lunar regolith. ${ }^{14}$

In early shuttle missions, leftover and half-consumed beverages constituted a major part of the trash. Uneaten food and beverages comprised nearly half the shuttle's wet trash. The introduction of dried beverages not only reduced the mass of the food supplied but also ensured that there was less of the unused beverages in the shuttle trash. Most dried powder form beverages are prepared either by freeze-drying or spray drying.

\section{Dried Beverages}

Technologies have driven the production of dried beverages to a level where beverages made from dried powder can have the same quality as fresh beverages. Recent studies even indicate the potential for freeze-dried alcohol, where the alcohol is first absorbed in a sugar derivative, cyclodextrin, prior to freeze-drying .

Dried powdered beverages have a number of advantages:

- Reduction of weight by between $80-90 \%$ and of volume by possibly up to over $95 \%$

- Can be bulk packed if needed, saving on volume

- Have longer shelf life

Some of the disadvantages of reconstituted beverages reported are: 
- Beverages have excessive sweetness.

- They tend to be thin and lack body.

- Lack pulp - thus not providing the mouth-feel of a natural beverage, particularly with pulpy beverages (e.g. Citrus).

- Dried beverages typically contain additives, sugar, citric acid, potassium or calcium phosphate, modified food starches, vegetable gums and oils and natural and artificial colors and flavors, which may or may not be desirable to the consumer.

Efforts are in progress in the world of food technology to overcome these disadvantages and it is very likely these disadvantages will be surmounted. As an example, there is a patented technology claiming to overcome the lack of "mouth-feel" and claims to produce a palatable and an acceptable beverage. ${ }^{15}$

With the vision of lunar habitats and the need to reduce mission costs by reducing mass, questions worth pondering are:

- What is the limit to which water content of food could be reduced before it is acceptable to the astronauts?

- Would it make sense to supply beverages in dried form for reconstitution?

The average minimum fluid intake for astronauts on a lunar mission is $2.5 \mathrm{~L}$ per day per crewmember. ${ }^{1}$ It is assumed that $1.25 \mathrm{~L}$ comes from the beverages while $1.25 \mathrm{~L}$ comes from the packaged food. Typical daily dry food requirement per crewmember per day is $0.625 \mathrm{~kg}$. ${ }^{1}$ Table 11 below presents savings based on different scenarios where the payload mass is lowered due to supply of dehydrated forms of food and beverages.

Table 11. Mass Savings Due to Supply of Dehydrated Forms of Food and Beverages

\begin{tabular}{|l|c|c|c|c|c|}
\hline & $\begin{array}{c}\text { Food } \\
\text { Dry } \\
\text { Content } \\
\text { Scenario }\end{array}$ & $\begin{array}{c}\text { Food } \\
\text { weight (at } \\
\text { launch) } \\
\text { (Kg) }\end{array}$ & $\begin{array}{c}\text { Beverage } \\
\text { weight (at } \\
\text { launch) } \\
\text { (Kg) }\end{array}$ & $\begin{array}{c}\text { Water } \\
\text { needed } \\
\text { through } \\
\text { recovery } \\
\text { (Kg) }\end{array}$ & $\begin{array}{c}\text { Savings - } \\
\text { reduction of } \\
\text { payload } \\
\text { mass } \\
\text { (\%) }\end{array}$ \\
\hline $\begin{array}{l}\text { Completely hydrated food and } \\
\text { liquid beverages }\end{array}$ & 0.625 & 1.875 & 1.25 & 0 & 0 \\
\hline $\begin{array}{l}\mathbf{5 0 \%} \text { water in food \& liquid } \\
\text { beverages }\end{array}$ & 0.625 & 1.25 & 1.25 & 0.625 & $20 \%$ \\
\hline $\begin{array}{l}\mathbf{5 \%} \text { water in food \& liquid } \\
\text { beverages }\end{array}$ & 0.625 & 0.657 & 1.25 & 1.218 & $39 \%$ \\
\hline $\begin{array}{l}\mathbf{5 0 \%} \text { water in food \& } \\
\text { powdered * beverages }\end{array}$ & 0.625 & 1.25 & 0.17 & 1.705 & $54 \%$ \\
\hline $\begin{array}{l}\mathbf{5 \%} \text { water in food \& powdered } \\
\text { beverages }\end{array}$ & 0.625 & 0.657 & 0.17 & 2.298 & $74 \%$ \\
\hline
\end{tabular}

*Assumes a mean of 1 part by weight of powdered beverage to 6.5 part by weight of water.

\section{Providing Beverages as Dried Powder}

At present, shuttle beverage is supplied as a dried powder. Reconstituting powdered beverage is a simple task. Specialized systems for reconstituting beverages are reported in a 1974 system design report ${ }^{11}$ and in a paper by Heidelbaugh (1996). ${ }^{16}$ Mixing powder and water on ISS or on the lunar surface should also be a simple task.

Based on current practices, it would appear that most of the beverages could be supplied in powdered form for a lunar habitat. As shown in Table 11, this is a major savings in mass. Based on the assumed 1 part powder in 7.5 parts by weight of water this can amount to a $35 \%$ weight reduction of payload. This is a conservative number for the powder to water ratio.

\section{Requirements and Specification on Food}

A detailed report on requirements and specifications on food was published as CR-134374 in August 1974. ${ }^{11}$ The specifications define required food for shuttle missions and this is likely to be the same basis for lunar missions. The requirement does not in any way eliminate the potential for all food to be supplied in dehydrated form. The only clearly defined guidelines on the menu are the goals of meeting human nutritional requirements. These include:

- $3000 \mathrm{kcal}$ per person/day

- $100 \mathrm{~g}$ protein per person/day

- Less than $35 \%$ of calories from fat

- Vitamins and Minerals must meet RDA standards

- Control of Specific nutrients as identified by physiological studies on Skylab 
The system selection criteria is expressed in a single statement - The system must provide maximum food acceptability at minimum system penalties, while satisfying the guidelines and requirements. The guidelines focus on the nutritional requirements and they can be supplied either in dehydrated form or hydrated form. Food acceptability is dependent on nutrition, safety, reliability and hedonic acceptability. On the first three, there are no allowable trade-offs while some trade off is permitted with hedonic acceptance if it can minimize system penalties.

6. Use of Dehydrated Food Alone with Recycled Waster for Meeting the Requirements for Humans

Not surprisingly, there are differences in opinion being debated about the nutritional quality and acceptability of dehydrated food. But, based on scientific principles, there is consensus in agreement that dehydrated food does not loose much of its nutritional value. Losses, if any in nutritional quality depends on the technology used for dehydration. The selection of appropriate technology can minimize the losses of nutritional value and quality of the beverage drink. This same principle applies for flavor components. As an example during dehydration of plants of the onion group, there can be the potential for loss of the allyl compounds that impart the characteristic onion flavor. This loss only happens if the plant cells are damaged, during the processing. The damage releases the enzyme, allinase, to react with the allyl compound with the subsequent loss of flavor through volatilization. However, this can be avoided by freeze-drying, which keeps the plant cells intact and retains the flavor. In some cases, low molecular weight compounds such as esters and fatty acids could volatilize during the dehydration. Despite these likely events, use of appropriate technology for drying and the ability to provide additives during the drying process could enable the dehydrated food to have even improved palatability. Thus, perhaps future technologies may find means of preventing the fatty acids and ester type volatiles from being lost in the dehydration process.

Vitamins $\mathrm{A}$ and $\mathrm{C}$ are often lost during dehydration as they are destroyed by heat and air. Appropriate drying methods for foods rich in Vitamin $\mathrm{A}$ and $\mathrm{C}$ need to be applied to minimize their losses.

Dried food has the same caloric content as the original food. In fact, on a weight for weight basis there is more calories in the dried food. For example, $100 \mathrm{~g}$ of fresh apricot have 51 calories while $100 \mathrm{~g}$ of dried apricots have 260 calories. It would be reasonable to assume that the food requirements as set out by NASA ${ }^{11}$ can be met with dehydrated food and recycled potable water.

The evidence indicates that dried food meets the nutritional and the physiological needs of the astronauts. A more fundamental question that perhaps needs investigation is the whether humans can accept dehydrated food for long durations from a psychological perspective. This evaluation is beyond the scope of this study. Without negative consequences on human psychology, the use of dehydrated food and dried beverages for astronauts should be considered for lunar habitats and other space exploration programs.

\section{Self Life and Palatability of Dehydrated Food}

Dehydrated food can last for a considerable period of time. For instance, a report from Brigham Young University indicates that the shelf life of dried foods can vary: 1 year for powered eggs, 15-30 years for dried apples, and $30+$ years for wheat and rice. ${ }^{17}$ Low storage temperature, vacuum packing, and the exclusion of oxygen promote extended shelf life.

Food acceptability is a product of four major criteria: nutrition, safety, reliability (stability) and palatability. Historically NASA has permitted palatability to be the only aspect of food acceptability to be compromised for mission needs. ${ }^{11}$ The psychobiological basis of palatability is a matter of controversy ${ }^{18}$ and it can be a highly variable sensory perception amongst a diverse community of humans. There are well-established standard sensory evaluations of palatability by appearance, texture, flavor and over-all acceptance using trained taste panels. Thus, if need be these techniques can be used to evaluate the palatability of dehydrated food and efforts can be made in processing to make the dehydrated food acceptable to astronauts. Perhaps, permitting a wide range in food palatability and acceptability may be beneficial and may be the mechanism to ensure that future space exploration missions can be truly international in nature. Dehydrated food may lose some of its body or flavor after reconstitution; however, this problem can be easily corrected by adding trace quantities of the ingredients that enhance the palatability during the rehydration process.

\section{Potential Utility of Surplus Water}

When examining the overall mission water balance, there are scenario characteristics that may lead to a potential water surplus. For example, with high levels of food hydration, significant amounts of recovered water from surface landers, recovery of water from waste and brine, and EVA suits that operate with low water loss rates, there could be a water surplus. These surpluses may also occur just by nominally meeting system requirements, and further reduction of water sources may not be desirable (e.g., maintaining an elevated level of food hydration for crew satisfaction). Although this additional water incurs additional mission cost, these water surpluses may be valuable assets to a mission in several ways. 
First, the water may be employed for radiation shielding. A primary concern for very long duration missions, such as lunar outpost missions, is the increased radiation exposure of the crew from both accumulative nominal dosing and the severe risks associated with intermittent radiation "storms". Vehicle radiation shielding varies with mission type, but a structural mass of $10 \mathrm{~g} / \mathrm{cm}^{2}$ is generally adequate. The pressure shell alone typically does not satisfy this requirement, therefore equipment, water tanks, material stowage, radiators etc. are judiciously positioned within the vehicle. Regardless, the crew requires additional protection for periods of elevated danger, such as solar particle events. Mitigation concepts include heavily shielded "safe havens", which may include areas such as an airlock surrounded by supplemental structure or stowage. If a substantial amount of surplus water would be made available during the mission, the potential exists for using this water to fill water-jacketed safe havens that would arrive empty. Alternatively, water could be stored in bags and positioned so as to provide protection. This practice would require considerable mission planning integration, and if sought would strongly influence how other subsystems manage water.

Another potential use for water is the production of fuels for use in fuel cells, including regenerative fuel cell technologies, for electrical energy production. This may also allow the rovers to extend their range. Additionally, water can be used to make a $\mathrm{H}_{2} / \mathrm{O}_{2}$ propellant. While the amount of water that can be recovered from a mission might not appear sufficient to produce significant quantities of propellant, current studies propose that further scavenging of $\mathrm{H}_{2}$ from lander tanks, in combination with ISRU production of $\mathrm{O}_{2}$ from regolith, can produce another $540 \mathrm{~kg}$ of water per lander in addition to the $450 \mathrm{~kg}$ recovered via fuel cell production of water. ${ }^{19}$

It was also proposed that robotic hoppers could be used as a means to explore robotically to extend the crews scientific reach or to supply lunar excursion missions with resupply materials (e.g., water, food, fuel). Human-rated hoppers are also possible to facilitate extended human exploration. These systems could potentially operate on $\mathrm{H}_{2} \backslash \mathrm{O}_{2}$ or $\mathrm{CH}_{4} \backslash \mathrm{O}_{2}$ fuels that could be generated during the mission. Once the approach of using water-based fuels is selected, it is likely that all water that can be economically produced/recovered will be desirable. This may include a strong component of ISRU operation, including $\mathrm{O}_{2}$ liberation via thermal processing of regolith and water recovery from the recently discovered small amounts $(\sim 1000 \mathrm{ppm})$ of free water present in regolith outside permanentlyshadowed areas.

Additional water can also be used to increase safety margins for off-nominal mission conditions. For example, resupply landers may experience delays or arrive with less than planned amounts of residual $\mathrm{H}_{2} \backslash \mathrm{O}_{2}$ for scavenging. Also, there may be unexpected water losses or contamination in life support systems or during water transfer from scavenging. A large stockpile of water, potentially serving other simultaneous functions such as radiation protection, could allow the crew to remain for extended periods to avoid loss of mission continuity. Furthermore, surplus water may supply future and unknown water needs, such as food production units that require large amounts of water.

\section{Overall Spreadsheet Water Balance Model}

In order to reveal the impact of waste management technology on the overall water balance, it is necessary to have an overall water balance of the life support system. In any system with water inputs, water loses, and water recycling the system can result in three alternatives: water accumulation (water rich), loss (water poor), or balance. Excess water in the life support system can be stored or the excess can be eliminated by actions such as reduction of recycling (WRS, brine water recovery, waste water recovery) or increase of water losses (more EVAs with water loss from venting). For a water poor life support system balance can be attained by expensive resupply of water or by increasing recycling.

Models of the water balance have been made by previous researchers. Two of the most recent models were chosen for evaluation of the effect waste management on the overall water balance. One model was obtained from R. Bagdigian, Lunar Surface Systems ECLSS System Manager, in August, 2009. The other model was obtained from K. Lange, a research engineer in the SIMA element of the ELS project. Neither of these two models were ideal for studying the effect of water recovery from waste. The Bagdigian model was chosen for upgrading and use in the current study due to its graphical component and easy input of assumptions. Using the Bagdigian model as a starting point, a new model was made, hereinafter referred to as the Surface Mission Mass Balance (SMMB).

For use in studying the water balance effects of waste management, some of the significant new features of the SMMB model included the following:

- A representative trash allocation that included more than food packaging.

- Urine solids are tracked.

- Water recovery is based on the solids content in the WRS and brine recovery systems.

- Food consumption, urine solids production and oxygen respiration were related mathematically so that the mass balance was maintained upon changes in the input assumptions. Note that closing the material balance 
required choosing one dependent water variable - the likely candidates were either drinks or water in the urine water in the urine was chosen as the dependent variable.

- Venting of water from the swing bed during EVA was related to perspiration and respiration.

- No feces is included in the EVA diapers (defecation during EVA is expected to be an unusual occurrence, and if it occurs, the feces could still be deposited into the rover or habitat toilets upon EVA return).

- Urine in diapers during EVA is proportional to $\mathrm{O}_{2}$ respiration and EVA duration.

- Urine in EVA diapers is included in the trash.

- Although no food consumption is assumed during EVA, the respiration of food was included as imputed food in order to complete the mass balance with oxygen consumption, urine solids production, and carbon dioxide production.

- All urine (except for urine in EVA diapers, which goes to trash) and condensate in the rover is returned to the core habitat WRS.

A diagram of the overall spreadsheet model is shown in Figure 2. More detail on the graphical component is shown in Figure 3.

The SMMB model was used to examine the overall water balance and the water contribution of the waste drying system. The model was also used to compare the effects of different mission assumptions.

Baseline assumptions (Case 1) were mostly obtained from NASA'S Lunar Surface Systems ECLSS System Manager - some additions and changes were made on waste quantity and water content based on the waste model development discussed above. An alternative set of assumptions (Case 2) was obtained from recent analyses done by the systems analysis group of the ELS Project. The key differences between Case 1 and Case 2 are indicated in Table 12 below. All the assumed parameters are listed in Table 13 below for Case 1 .

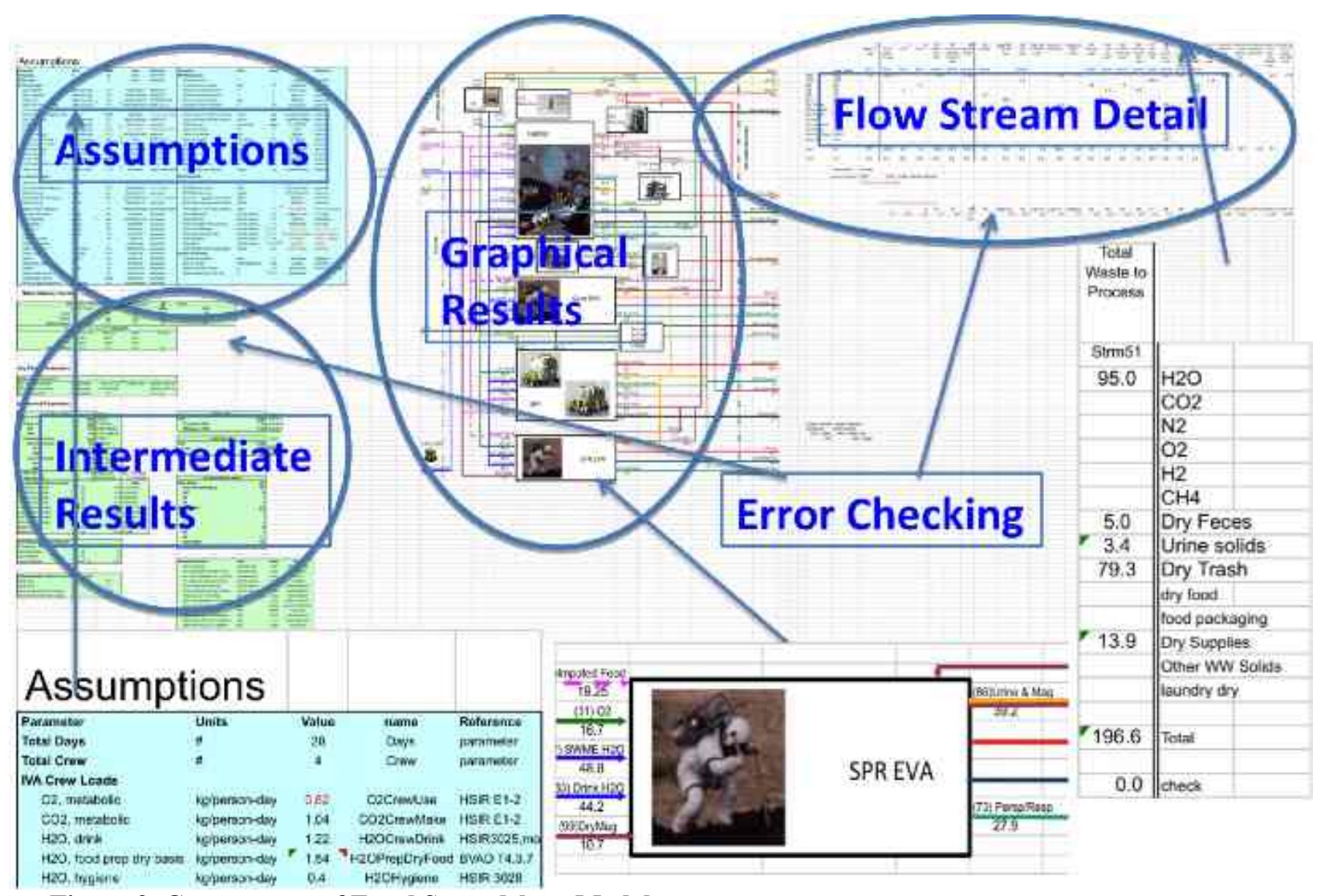

Figure 2. Components of Excel Spreadsheet Model 


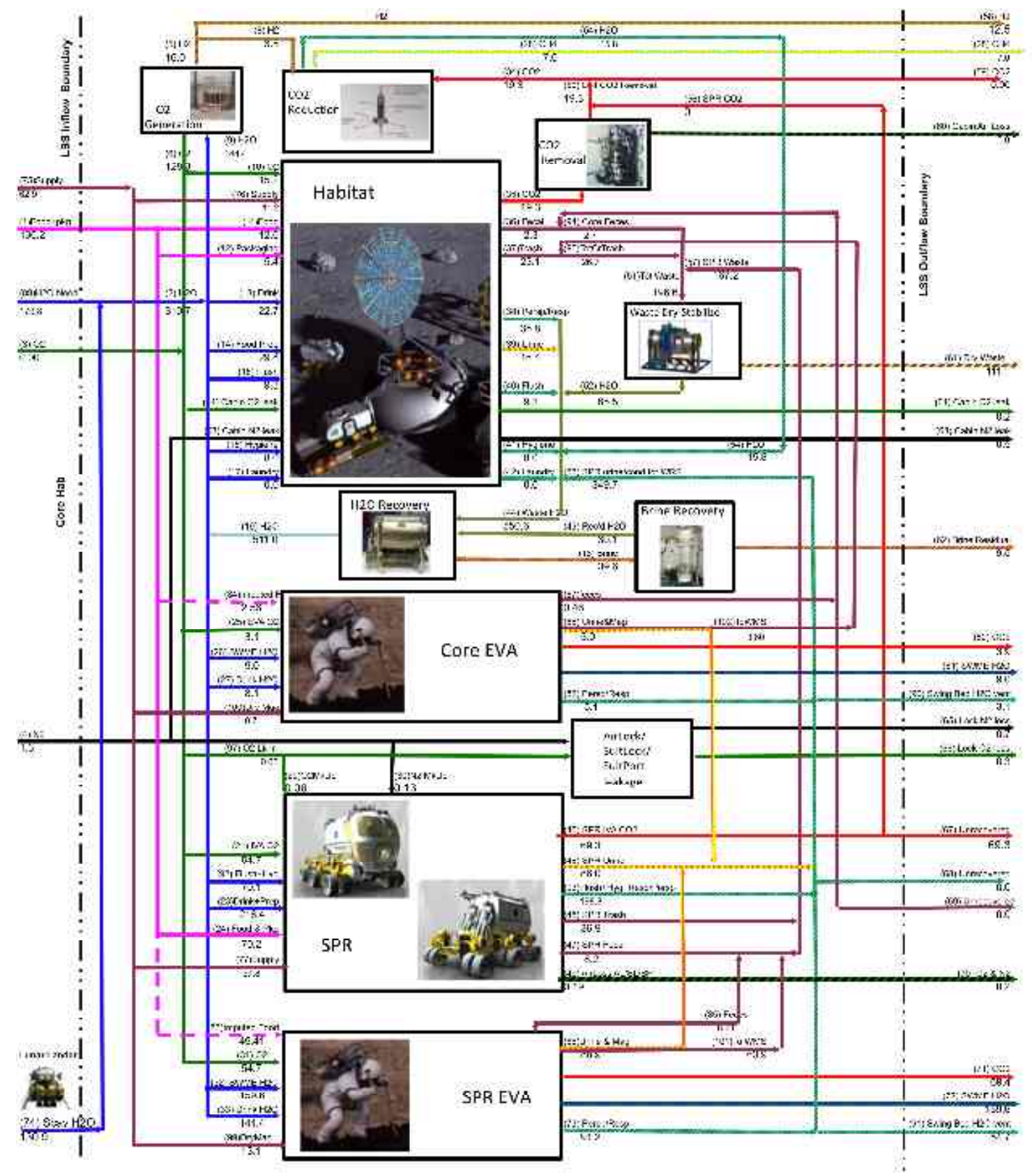

Figure 3. Graphical Component of Spreadsheet Model

Table 12. Key Differences in Case Assumptions

\begin{tabular}{|l|l|l|}
\hline Assumption & Case 1 Baseline & Case 2 Alternative \\
\hline EVA amount & High: based on 8 hr/EVA & Low: based on 3 hr/EVA \\
\hline Water in food & Dehydrated: 3\% water & Partially hydrated: 30\% water \\
\hline Water scavenged from Lunar Lander & $561 \mathrm{~kg}$ & $676 \mathrm{~kg}$ \\
\hline Time between Lunar Landers & 120 days & 105 days \\
\hline \hline $\begin{array}{l}\text { Result: 28 day water deficit/excess for the } \\
\text { overall system water balance }\end{array}$ & $180 \mathrm{~kg}$ deficit (water poor) & $\begin{array}{l}102 \mathrm{~kg} \text { excess } \\
\text { (water rich) }\end{array}$ \\
\hline
\end{tabular}


Table 13 Detailed Assumptions for the Baseline Case (Case 1)

\begin{tabular}{|c|c|c|c|c|c|}
\hline Parameter & Units & Value & Parameter & Units & Value \\
\hline Total Days & \# & 28 & SPR Parameters & & \\
\hline Total Crew & $\#$ & 4 & \# Crew per SPR & $\#$ & 2 \\
\hline IVA Crew Loads & & & Long excursion duration & days & 14 \\
\hline $\mathrm{O}_{2}$, metabolic & $\mathrm{kg} /$ person-day & 0.82 & Number long excursions & \# & 1 \\
\hline $\mathrm{CO} 2$, metabolic & $\mathrm{kg} /$ person-day & 1.04 & \# SPRs per long excursion & $\#$ & 2 \\
\hline $\mathrm{H}_{2} \mathrm{O}$, drink & $\mathrm{kg} /$ person-day & 1.22 & Short excursion duration & days & 3 \\
\hline $\mathrm{H}_{2} \mathrm{O}$, food prep dry basis & $\mathrm{kg} /$ person-day & 1.54 & Number short excursions & \# & 3 \\
\hline $\mathrm{H} 2 \mathrm{O}$, hygiene & $\mathrm{kg} /$ person-day & 0.4 & \# SPRs per short excursion & \# & 2 \\
\hline Fraction solids in $\mathrm{Hyg} \mathrm{H}_{2} \mathrm{O}$ & fraction & 0.002 & Fecal return fr SPR \& rec & yes/no & yes \\
\hline $\mathrm{H}_{2} \mathrm{O}$, persp/resp & $\mathrm{kg} /$ person-day & 1.93 & Trash return fr SPR/Rec & yes/no & yes \\
\hline $\mathrm{H}_{2} \mathrm{O}$, laundry & $\mathrm{kg} /$ person-day & 7.33 & CO2 Removal & open/closed & open \\
\hline Urine solids & $\mathrm{kg} /$ person-day & 0.073 & Cabin air volume & $\mathrm{m}^{3}$ & 11 \\
\hline $\mathrm{H}_{2} \mathrm{O}$, urinal flush & $\mathrm{kg} /$ person-day & 0.5 & Cabin air pressure & psia & 8 \\
\hline Food, dry, for IVA day & kg/person-day & 0.66 & Cabin air oxygen & mol fraction & 0.3 \\
\hline Fraction water in food & fraction water & 0.03 & Cabin air leakage & vol\%/day & 0.05 \\
\hline Food packaging & $\mathrm{kg} /$ person-day & 0.27 & Airlock & yes/no & no \\
\hline Fecal, dry mass & $\mathrm{kg} /$ person-day & 0.032 & Airlock gas volume & $\mathrm{m}^{3}$ & 5.4 \\
\hline Fecal, $\mathrm{H}_{2} \mathrm{O}$ & $\mathrm{kg} /$ person-day & 0.091 & Suitlock & yes/no & no \\
\hline Dry Supply Solids total & $\mathrm{kg} /$ person-day & 0.562 & Suitlock gas volume & $\mathrm{m}^{3}$ & 5.4 \\
\hline Trash, $\mathrm{H}_{2} \mathrm{O}$ & fraction water & 0.279 & AL/SL/SP gas rec. eff. & vol frac & 0.9 \\
\hline Core Hab Parameters & & & EVA Parameters & & \\
\hline Water Recovery & yes/no & yes & EVA rate from Core & \#/week & 3 \\
\hline Frac (Ur) Solids WRS brine & $\%$ & 0.2 & SPR EVA rate, short & \#/day & 1 \\
\hline Brine Recovery & yes/no & yes & SPR EVA rate, long & \#/week & 5 \\
\hline Frac Solids Brine Residual & $\%$ & 0.83 & $\begin{array}{l}\text { EVA crew - e.g } 2 \text { persons } \\
\text { on EVA }\end{array}$ & \#/EVA & 2 \\
\hline Waste Drying & yes/no & yes & $\begin{array}{l}\text { EVA duration (avg } \\
\text { duration) }\end{array}$ & $\mathrm{hr} / \mathrm{EVA}$ & 8 \\
\hline Waste Drying, efficiency & $\%$ & 90 & $\begin{array}{l}\text { Time basis for EVA (see } \\
\text { EVA O2) }\end{array}$ & hours & 8 \\
\hline Oxygen Generation & yes/no & yes & EVA SWME $\mathrm{H}_{2} \mathrm{O}$ & kg/EVA-person & 2.1 \\
\hline $\mathrm{CO}_{2}$ Reduction & yes/no & yes & EVA drink $\mathrm{H}_{2} \mathrm{O}$ & kg/EVA-person & 1.9 \\
\hline Sabatier & yes/no & yes & $\begin{array}{l}\text { EVA O2 usage for } 8 \text { hours } \\
\text { EVA }\end{array}$ & kg/EVA-person & 0.72 \\
\hline Bosch & yes/no & no & EVA CO2 generation & kg/EVA-person & 0.91 \\
\hline Laundry & yes/no & no & EVA swing bed $\mathrm{H}_{2} \mathrm{O}$ loss & kg/EVA-person & 0.72 \\
\hline Cabin air volume & $\mathrm{m}^{3}$ & 78 & EVA perpiration & kg/EVA-person & 0.91 \\
\hline Cabin air pressure & psia & 8 & Mag diaper & kg/EVA-person & 0.173 \\
\hline Cabin air oxygen & mol fraction & 0.3 & $\begin{array}{l}\text { EVA: fraction urine to Mag } \\
\text { diaper }\end{array}$ & fraction & 0.67 \\
\hline Cabin air leakage & vol\%/day & 0.05 & Lander Scavenging & & \\
\hline Airlock & yes/no & yes & Time betw Landings & days & 120 \\
\hline Airlock gas volume & $\mathrm{m}^{3}$ & 7.2 & Pole or Equator & $\begin{array}{l}\text { Pole/Equator/N } \\
\text { o }\end{array}$ & Pole \\
\hline Suitlock & yes/no & no & Water per Polar Landing & $\mathrm{kg}$ & 561 \\
\hline Suitlock gas volume & $\mathrm{m}^{3}$ & 6.5 & $\begin{array}{l}\text { Ratio Equator/Pole } \mathrm{H}_{2} \mathrm{O} \\
\text { Rec }\end{array}$ & \# & 0.771 \\
\hline Suitport gas volume & $\mathrm{m}^{3}$ & 0.035 & & & \\
\hline AL/SL/SP gas recovery eff. & vol fraction & 0.9 & & & \\
\hline
\end{tabular}


Table 14. Case Comparison of Water Recovery

\begin{tabular}{|l|l|l|l|}
\hline & $\begin{array}{l}\text { Primary Water Recovery } \\
\text { System } \\
\text { (kg) }\end{array}$ & $\begin{array}{l}\text { Brine System } \\
\text { Water Recovery } \\
\text { (kg) }\end{array}$ & $\begin{array}{l}\text { Waste Drying System Water } \\
\text { Recovery } \\
\text { (kg) }\end{array}$ \\
\hline Baseline Case (Case 1) & 511 & 31 & 86 \\
\hline Alternative (Case 2) & 456 & 30 & 57 \\
\hline
\end{tabular}

The results from the two cases in the SMMB model show substantial amounts of water being recovered from the waste drying system in a 28 day period: $57 \mathrm{~kg}$ to $86 \mathrm{~kg}$ of water in 28 days. This compares with 456 to $511 \mathrm{~kg} /(28$ days) recovered by the primary water processor and 30 to $3130 \mathrm{~kg} /(28$ days $)$ of water recovered by the brine processor. See Table 14. Thus water recovery from waste is a significant contributor to the water balance. For the assumptions used in these cases the waste drying system is recovering somewhat more water than the brine water recovery system.

The effect of the two different cases on the overall water balance is also striking. Case 1 shows that the life support system is water poor by $180 \mathrm{~kg}$ every 28 days, and Case 2 shows a life support system that is water rich by $102 \mathrm{~kg}$ every 28 days. This is swing of over $3600 \mathrm{~kg}$ of water over a year.

An attempt was made to compare the water balance predictions with the predictions made by the Lange spreadsheet model. Some of the numbers for key variables were very close. For instance the water vented from the SWME cooling system and the carbon dioxide removal swing beds in the EVA suits were exact to 3 significant figures when comparable EVA quantity assumptions were made. One comparison of the overall system predictions was made. It was attempted to tailor the input assumptions for Case 2 above to match the Lange assumptions for what is called a scenario $121 \mathrm{~s}$ case with $1159 \mathrm{~kg}$ of water from each Lunar Lander. The Lange model predicted an excess of about $750 \mathrm{~kg}$ in 180 days, and the scaled prediction from the SMMB model was about $1300 \mathrm{~kg}$ in 180 days. Both models predicted an excess of water, but the difference between 750 and 1300 is nontrivial. Further analysis is planned to resolve the reason for the different predictions. However, the results for the Lange model are for less excess water, consequently it is expected that the Lange model would predict a greater deficit of water for the Case 1 assumptions (discussed above) of higher EVA, dehydrated food, and less water from the Lunar Lander.

The Case 1 assumptions (Table 13) represent our current best estimate as to the appropriate assumptions for a lunar mission. As listed in table 12, key assumptions that strongly affect the water balance are EVA quantity, food hydration, water scavenging, and Lander frequency. The EVA quantity and Lander frequency assumptions were provided by the Lunar Surface Systems ECLSS System Manager. The assumption of dehydrated food was made because this saves water, and because it appears that dehydrated food can satisfy crew requirements. The assumption regarding the amount of water recoverable from the Lunar Lander is based on hydrogen as the limiting reactant - the hydrogen vents off as discussed above, and without currently nonexistent recovery hardware, only part of the initial residual hydrogen remains long enough for conversion to water. The Case 1 assumptions result in a water poor life support system. In a water poor situation, a $\mathrm{kg}$ of water recovered in the life support system is a $\mathrm{kg}$ of water that does not need to be brought from Earth. Although other assumptions can produce a water rich prediction, in an environment of uncertainty it is prudent to assume that the life support system will be water poor, and to develop the technologies that can save as much water as possible.

\section{Conclusion and Recommendations}

This analysis evaluated the potential for solid waste processing to contribute to the overall water balance of a lunar outpost mission. Two major analysis thrusts were performed - generation of a waste model and evaluation of the overall water balance.

The solid waste model that was generated can estimate the amount of solid waste and the associated water content of that waste. This model utilized a spreadsheet format to allow users to easily alter mission parameters and waste design and assumption values. It is suggested that this model may serve as a beginning repository for this mission, and that it be refined as more refined data become available. A principal finding of the model is that the waste contains substantial amounts of water under the mission assumptions employed. With respect to the entire waste stream (without wastewater brine), each crewmember produces a nominal daily average of $1.49 \mathrm{~kg}$ at a moisture content of $41.9 \%$, or $0.62 \mathrm{~kg}$ of water/CM-day. Over this mission duration (180 days with a $30 \mathrm{crew}$ overlap), $599 \mathrm{~kg}$ of unbound water is anticipated. A large portion of this amount $(0.52 \mathrm{~kg} / \mathrm{CM}$-day) is due to the substantial quantity of urine expected to be contained within EVA MAGs, and relatively high rates of EVA scheduled. Relatively high rates of wastewater brine production are also predicted, and if not recovered, this would add significantly to the amount of water to be managed by the WMS system. Based on this evidence, and because 
waste processing systems can readily remove greater than $90 \%$ of the moisture in waste, it appears prudent to explore the potential for recovery of water.

The overall analysis identified and evaluated several key factors that exert a controlling influence on the overall water balance. These factors include the loss of water through EVA suit cooling, the use of scavenged $\mathrm{H}_{2}$ and $\mathrm{O}_{2}$ residuals from Altair landers, the degree of food hydration, and the degree of water recovery from solid waste and wastewater brine. An examination of lander scavenging indicated that significant amounts of water can be recovered, but the issues of slow water production by the fuel cell, hydrogen venting losses, sensitivity to mission location, water transport to core habitat, and lack of assured levels of residuals render the actual amount of recoverable resources to be uncertain. Additionally, further work is required to determine the overall operational cost and ESM of scavenging equipment. Water use for EVA suit cooling, potentially the single largest nominal loss of water on the mission, is also susceptible to significant variation due to mission location, EVA scheduling, and evolving suit designs that decrease or eliminate water loss. Decreasing food hydration is an area that can also reduce water supply costs if there is significant water recovery from other subsystems. Food hydration can always be increased, if feasible, to decrease or eliminate system-level water deficits in water-poor scenarios.

Water recovery from solid waste was shown to be an important water source in the overall water balance. Depending on the actual amount of urine that is contained in EVA MAGs, water recovery from waste can be roughly equivalent or exceed that anticipated from wastewater brine. This matches favorably with the generalized need to dewater wastes and brine for safety, volume reduction, long-term storage needs, and transport through airlocks. It is anticipated that further research and development could improve these estimates. Additional analysis for technology down-selection will be required as ongoing mission planning provides more detailed requirements and integration guidelines.

Having established the value of water recovery from waste, another factor to consider is the higher rate of waste and wastewater processing needed to accommodate high amounts of excursion away from the core habitat. During extended rover excursions, wastewater and solid wastes would be stored for later processing in the core habitats. This could result in large amounts of wastewater and waste that must be processed in order to supply water for the next excursion. If these materials must be processed in a short period of time, this increases the required processing rate and ESM as compared to systems that could operate more slowly/frequently. This could also be addressed by automated processing and/or optimizing crew residency within the core habitat.

The overall water balance analysis indicated a high level of sensitivity to mission assumptions. The water balance model developed showed that differing prevailing assumptions of scavenging, EVA rates, and food hydration resulted in the mission being either water-rich or water-poor. This indicates that further system definition is required, and that water recovery mechanisms should be explored until determined otherwise.

Recommendations:

- An overall conclusion from both the waste model and water balance analysis is that a significant amount of water is present in solid wastes, and that given the demonstrated potential for an overall system water deficit, that there should be continued development of waste technologies for water recovery.

- Additionally, waste management operational issues indicate a need for a stronger commitment to waste stabilization for crew safety and storage. These efforts should also address the needs for future mission to satisfy planetary protection requirements.

- It is recommended that the solid waste model developed in this effort serve as a basis for centralizing evolving solid waste composition and production information.

- A solid waste database or "catalogue" should be also established that allows all mission sub-systems to accurately $\log$ and characterize anticipated wastes and their production rates. This information should be a controlled, web-based document that allows continual updating. The solid waste model would then utilize this information to further refine its contents.

- Follow-on studies are recommended that further develop and refine overall water mass balance studies/options for the lunar outpost mission. Current variance in both model assumptions and assessment of available resources (e.g., scavenged water) exhibits significant uncertainty.

\section{References}

${ }^{1}$ Duffield, B.E., Anderson, M.S., "Exploration Life Support Baseline Values and Assumptions Document," NASA Document JSC-64367, December 2008.

${ }^{2}$ Duffield, B.E., "Exploration Life Support Reference Missions Document,” NASA JSC document JSC-64367, January 2008

${ }^{3}$ Human Systems Integration Requirements (HSIR), CxP 70024, NASA Constellation Program, 2009.

${ }^{4}$ Linne, D.L., Plachta, D.W., Chato, D.J., Loyselle, P.L., Sutherlin, S.G., Notardonato, W.U., Fittje, J.E., Poast, K.I., Kashani, A., Hornsby, L.S., Prokopius, K.P. 2009. "Feasibility of Scavenging Propellants from Lander Descent Stage to Supply Fuel Cells 
and Life Support," AIAA paper no. 2009-6511, AIAA SPACE 2009 Conference \& Exposition, Pasadena, California, September 2009.

${ }^{5}$ Polsgrove, T.P., Button, R.M., Linne, D.L., "Altair Lunar Lander Consumables Management," AIAA paper N. 2009-6589, AIAA SPACE 2009 Conference \& Exposition, Pasadena, California, September 2009.

${ }^{6}$ Jones, H., "Spacesuit Cooling on the Moon and Mars," SAE Technical Paper No. 2008-01-2418 Society of Automotive Engineers, 39th International Conference on Environmental Systems, 2009.

${ }^{7}$ Jones, H., "Lunar Base Life Support Mass Flow and Recycling," SAE Technical Paper No. 2008-01-2184, Society of Automotive Engineers, 38th International Conference on Environmental Systems, 2008.

${ }^{8}$ Griffen, B. N., Spampinato, P., Wilde, R.C. 2000. "Extravehicular Activity (EVA) Systems,” in W. K. Larson, and L. K. Pranke, eds., Human Spaceflight: Mission Analysis and Design, McGraw-Hill, New York, 2000.

${ }^{9}$ Eckhart, P., "Spaceflight Life Support and Biospherics,” Kluwer Academic Publishers, 1996.

${ }^{10}$ Alptekin, G.O, Cates, M.C., Bernal, C.A., Dubovik, M., Paul, H.L., "Development of a Rapid Cycling $\mathrm{CO}_{2}$ and $\mathrm{H}_{2} \mathrm{O}$ Removal Sorbent," 37th International Conference on Environmental Systems, SAE Technical Paper 2007-01-3271, 2007.

11 "Space Shuttle/ Food System Study - Vol 1. Final Report: System Design Study," Contract NAS9-13138 JSC, Houston, TX; Prepared by the Pillsbury Co., NASA CR-134374. August 1974.

${ }^{12}$ Lane, H., Kloeris, V., Perchonok, M., Zwart, S., Smith, S.M., "Food and Nutrition for the Moon Base: What We Have Learned in 45 Years of Spaceflight," Nutrition Today, May/June, Vol. 42:3 pp. 102-110, 2007.

${ }^{13}$ Bourland, C.T., The Development of Food Systems for Space," Trends in Food Science and Technology 4:271, 1993.

${ }^{14}$ Ignattiev, A., Heiss, K and P. van Susante, "ISRU based development of a lunar water astroparticle observatory," Acta Astronautica 61: 496-499ISRU, 2007.

${ }^{15}$ Owades, J.L., "Method of making a beverage Composition," US Patent 4233334, Nov. 11, 1980.

${ }^{16}$ Heidelbaugh, N.D., "Space flight Feeding Concepts: Characteristics, Concepts for Improvement, and Public Health Implications," JAVMA; 149:1662, 1996.

${ }^{17}$ Eliason, D., Lloyd, M., "Nutritional Adequacy and Shelf Life of Food Storage," technical paper Women's Conference, BYU, Utah, 2005.

${ }^{18}$ Yeomans, M.R., Blundell J.E., Lesham M., "Palatability: Response to Nutritional Need or Need-free Stimulation of Appetite,” Br. J. Nutrition. 92 Suppl1, S3-S14, 2004.

${ }^{19}$ Santiago-Maldonado, E., "LSS Excess Water Study.” ISRU DSE, LSS October 5, 2009. 